\title{
Emerging role of alternative splicing of CRF1 receptor in CRF signaling
}

\author{
Michał A. Żmijewski ${ }^{\boxplus}$ and Andrzej T. Slominski² \\ 1Department of Molecular Enzymology, Intercollegiate Faculty of Biotechnology of University of Gdańsk and Medical University of Gdańsk, \\ Gdańsk, Poland; 2Department of Pathology and Laboratory Medicine, Center for Cancer Research, University of Tennessee Health Science \\ Center, Memphis, TN, USA
}

\begin{abstract}
Alternative splicing of mRNA is one of the most important mechanisms responsible for an increase of the genomic capacity. Thus the majority of human proteins including G protein-coupled receptors (GPCRs) possess several isoforms as a result of mRNA splicing. The corticotropin-releasing factor (CRF) and its receptors are the most proximal elements of hypothalamic-pituitaryadrenal axis (HPA) - the central machinery of stress response. Moreover, expression of CRF and regulated activity of CRF receptor type 1 (CRF1) can also play an important role in regulation of local stress response in peripheral tissues including skin, gastrointestinal tract or reproductive system. In humans, expression of at least eight variants of CRF1 mRNA ( $\alpha, \beta, c, d, e, f, g$ and $h$ ) was detected and alternative splicing was found to be regulated by diverse physiological and pathological factors including: growth conditions, onset of labor, during pregnancy or exposure to ultraviolet irradiation. The pattern of expression of CRF1 isoforms is cell type specific and recently has been linked to observed differences in responsiveness to CRF stimulation. In the proposed model of regulation of CRF-signaling, isoform CRF1a plays a central role. Other isoforms modulate its activity by oligomerization, leading to alteration in receptor trafficking, localization and function. Co-expression of CRF1 isoforms modulates sensitivity of cells to the ligands and influences downstream coupling to G-proteins. The other possible regulatory mechanisms include fast mRNA and/ or protein turnover or decoy receptor function of CRF1 isoforms. Taken together, alternative splicing of CRF1 can represent another level of regulation of CRF-mediated stress responses at the central and peripheral levels. Chronic stress or malfunction of the HPA-axis have been linked to numerous human pathologies, suggesting that alternative splicing of CRF1 receptor could represent a promising target for drugs development.
\end{abstract}

Keywords: corticotropin-releasing factor, corticotropin-releasing factor receptor type 1, G-proteins, GPCR, hypothalamus-pituitaryadrenal axis, skin stress.

Received: 20 August, 2009; revised: 02 March, 2010; accepted: 15 March, 2010; available on-line: 16 March, 2010

\section{HPA AXIS}

Organisms do not always live under optimal conditions and are frequently subjected to various external and internal stimuli, thus during evolution a global system of a stress response was developed. In mammals, the hypothalamus-pituitary-adrenal axis (HPA) plays the central role in the regulation of stress response by production and secretion of important regulatory peptide intermediates and steroid hormones (Fig. 1). The classic signaling cascade of stress response is triggered by the synthesis of corticotropin-releasing factor (CRF, $\mathrm{CRH}$ ) in the hypothalamus (Vale et al., 1981; Smith \& Funder, 1988; Chrousos \& Gold, 1992). Activation of CRF receptor type 1 (CRF1) in the anterior pituitary results in production of pro-opiomelanocortin (POMC) with its subsequent processing to adrenocorticotropin (ACTH), and lipotropins (LPH) (Vale et al., 1981; Smith \& Funder, 1988). LPH can be further processed to $\beta$-endorphin, while ACTH to $\alpha$-melanocyte-stimulating hormone $(\mathrm{MSH})$. ACTH is responsible for stimulation of production and secretion of steroids in adrenal glands (cortisol-human, corticosterone-rodents) and this process is mediated by melanocortin receptor type 2 (MC2). MSH stimulates melanogenesis in the skin via interaction with MC1 receptor (MC1) (Pawelek et al., 1992; Abdel-Malek et al., 2000; Slominski et al., 2004b; Bohm et al., 2006). $\beta$-Endorphin is a powerful agonist of the $\mu$-opioid receptor and similarly to other opioids works as an analgesic, promoting good mood and relaxation factors (Charmandari et al., 2005). Circulating cortisol inhibits synthesis of CRF (Roche et al., 1988) and POMC forming a negative feedback, responsible for maintaining of body homeostasis (for reviews see: Slominski et al., 2000b; Bale \& Vale, 2004; Charmandari et al., 2005; Hillhouse \& Grammatopoulos, 2006). In an addition $\alpha-\mathrm{MSH}$ (Luger et al., 1999; Bohm et al., 2006; Eves et al., 2006), intermediates of melanogenesis and melanin itself were found to affect immune response in the skin (Slominski et al., 1998b; Slominski, 2009a). Moreover, ACTH (Hunt et al., 1994; Abdel-Malek et al., 1995; Luger et al., 1999;

凶e-mail: mzmijews@biotech.ug.gda.pl

Abbreviations: AC, adenylate cyclase; ACTH, adrenocorticotropic hormone; AP-1, activator protein 1; AtT-20, a pituitary adenoma cell line; COS- 1 and COS-7, CARE, $\mathrm{Ca}^{2+}$ response element; CRE, CAMP response element; CREB, CAMP response element binding protein; CRF (CRH), corticotropin-releasing factor (hormone); CRF1 (CRH-R1, CRHR1, CRFR1), corticotropin-releasing factor receptor type 1; EC1-3, extracellular coil 1-3; ECD, extracellular domain (ligand binding domain); END, endorphin; G-protein, guanine nucleotide-binding protein; $G_{a s} G_{a,} G_{a q / 11}, G_{a i}$ and $G_{a z}, G$-protein subunits; GPCR, G-protein coupled receptor; HaCaT, immortalized human keratinocytes; HPA, hypothalamic-pituitary-adrenal axis; IC1-3, internal coil 1-3; IP inositol trisphosphate; $\mathrm{LPH}$, lipotropin; $\mathrm{MSH}$, melanocyte stimulating homone; NF-KB, nuclear factor K-light-chain-enhancer of activated B cells; PKA, protein kinase $A$; PKC, protein kinase C; PLC, phospholipase C; POMC, Pro-opiomelanocortin; SNP, single nucleotide polymorphism; SV40-transformed CV-1 kidney cell lines of African green monkey (Cercopithecus ae thiops); 7TM, seven a-helical transmembrane domain; UCN-I, II, III, urocortins I, II and III; UV, ultraviolet. 


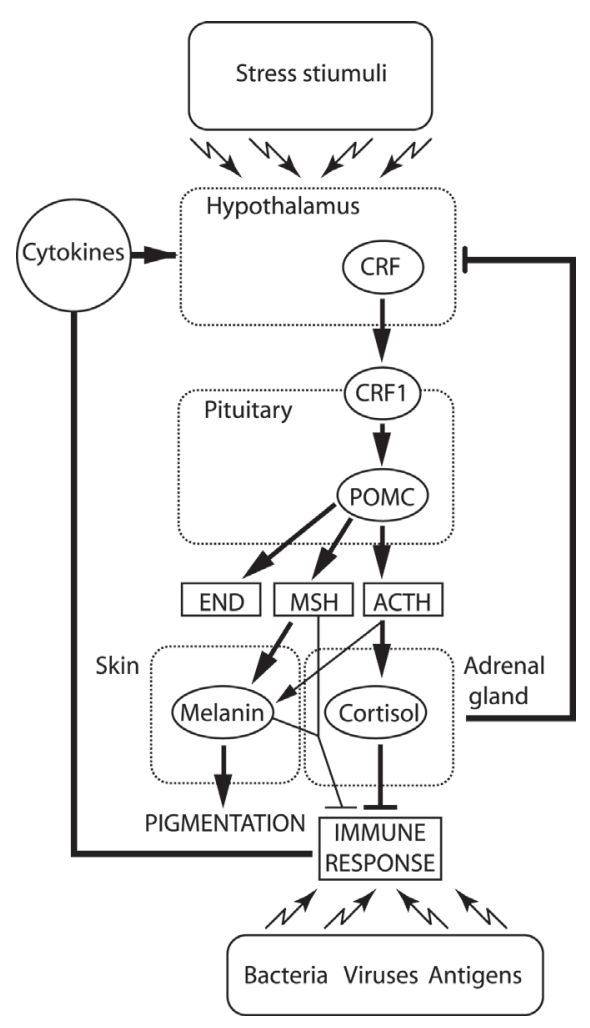

Figure 1. Mechanism of systemic response to stress through activation of the hypothalamic-pituitary-adrenal axis (HPA).

The signaling cascade is initiated by corticotropin releasing factor production (CRF) in the hypothalamus, followed by activation of the CRF receptor (CRF1) in the pituitary and subsequent synthesis of pro-opiomelanocortin (POMC). POMC-derived peptides: adrenocorticotropic hormone (ACTH), melanocortin (MSH) and endorphin (END), activate a series of key metabolic pathways including steroidogenesis in the adrenal gland (ACTH) and melanogenesis in the skin (MSH, ACTH and END). Synthesis and release of cortisol inhibits the immune response and form a negative feedback loop for CRF and POMC synthesis. In addition ACTH can trigger melanogenesis in the skin, and MSH, melanin and intermediates of melanogenesis suppress immune response. Modified after (Slominski et al., 2000b). See text and citations within for details.

Slominski et al., 2004b), and END (Kauser et al., 2003) also stimulate melanogenesis in the skin. Thus, there is crosstalk between POMC derived peptides (Pawelek et al., 1992; Slominski et al., 1993; 2000b; Luger et al., 1999).

The HPA axis is responsible for regulation of autonomic, behavioral, cardiovascular, endocrine, gastrointestinal, immune and reproductive functions on a central level in response to stress (see for extensive reviews: Chrousos, 1995; Slominski et al., 2000b; Grammatopoulos \& Chrousos, 2002; Hillhouse et al., 2002; Tache \& Bonaz, 2007). Acute or chronic stress and/or deregulation of the CRF system has been implicated in the pathophysiology of various psychological, neurological and endocrinological conditions, including anxiety, depression, abnormal pain and fatigue, sleep disorder (Hauger et al., 2006; Clarke et al., 2008; Wasserman et al., 2008), drug and alcohol abuse (Clarke et al., 2008), allergy, inflammation (Karalis et al., 1991; Slominski et al., 2001), gastrointestinal diseases ('Tache \& Bonaz, 2007), psoriasis (Arck \& Paus, 2006; Slominski, 2009b) and acne (Ganceviciene et al., 2009). Thus, CRF and its receptors are potential targets for therapy of several human conditions (Bale \& Vale, 2004; Hemley et al., 2007; Slominski et al., 2008; Paschos et al., 2009).
Recent studies revealed that the expression of the elements of the HPA-axis is not limited to the neuroendocrine system, but its elements are also found in immune cells (Slominski, 2006; Slominski et al., 2000b), the digestive system (Tache \& Bonaz, 2007), the skin and its appendages (Slominski \& Mihm, 1996; Slominski et al., 1996b; 2007a), the reproductive system (Hillhouse \& Grammatopoulos, 2006) and many other tissues (Slominski et al., 2000b; 2007b; Hillhouse \& Grammatopoulos, 2006; Zmijewski et al., 2007).

The peripheral expression of CRF, its receptors and other elements of the HPA axis are crucial in locally targeted regulation of the stress response, which is important in organs constantly subjected to stress insults like the skin (Slominski et al., 1999; 2000b; Slominski \& Wortsman, 2000; Arck et al., 2006).

\section{CRF RECEPTORS AND THEIR LIGANDS}

CRF and its receptors play a central role in initiation and regulation of the central response to the stress (Spiess et al., 1981; Vale et al., 1981; Owens \& Nemeroff, 1991; Charmandari et al., 2005). CRF receptors belong to class B (secretin family) of $G$ protein-coupled receptors (GPCRs), where the ligands are peptides of $>27$ aminoacid residues, produced mostly by endocrine cells (Perrin \& Vale, 1999; Hillhouse \& Grammatopoulos, 2006). Other members of class B are receptors for calcitonin, glucagon, glucagon-like hormone, secretin, parathyroid hormone (PTH), pituitary adenylate-cyclase-activating peptide, (PACAP), growth-hormone-releasing hormone (GHRH) (Miller et al., 2007; Lagerstrom \& Schioth, 2008).

\section{Ligands}

CRF is a 41-amino-acid peptide produced from the 18 $\mathrm{kDa}(21 \mathrm{kDa}$ after posttranslational modification) precursor - pro-CRF (pro-CRH) (Spiess et al., 1981; Vale et al., 1981; Roche et al., 1988). CRF is synthesized predominantly in the paraventricular nucleus of the hypothalamus, but it was also found in the peripheral tissues, including: reproductive organs (Asakura et al., 1997; Clifton et al., 1998), liver, stomach, spleen, adrenal and thyroid glands, bowel (Slominski et al., 2000b; Charmandari et al., 2005; Hillhouse \& Grammatopoulos, 2006), retinal pigment epithelium (Zmijewski \& Slominski, 2009a), kidneys (Slominski et al., 2007b) and skin (Slominski et al., $2001 ; 2006 b)$. Its expression is stimulated by several neurotransmitters (serotonin, acetylcholine) (Ohmori et al., 1995; Laflamme et al., 1999), neuropeptides (arginine vasopressin, neuropeptide Y, enkephalin) (Itoi et al., 1999) and cytokines (tumor necrosis factor (TNF), interleukins 1 and 6) (Turnbull \& Rivier, 1999; Slominski, 2006). CRF is expressed in human skin (Slominski et al., 1995; 1996a; 1998a; 2000a) and its expression is stimulated by external factors including ultraviolet (UV) irradiation, lipopolysaccharide (LPS) or factors raising cAMP level (Slominski et al., 1996a; 1998a; 2006b; Zbytek \& Slominski, 2007). An inhibitory effect on CRF production was shown for glucocorticoids, estrogens, dynorfin and substance P (reviewed in: Slominski et al., 2000b). In addition to CRF, a family of CRF receptor ligands includes mammalian urocortins: UCN-I (urocortin 1), UCN-II (stresscopinrelated peptide, urocortin 2) and UCN-III (stresscopin, urocortin 3); fish urotensin-I and sauvagine found in frog (Perrin \& Vale, 1999; Slominski et al., 2000b; Arck et al., 2006; Hillhouse \& Grammatopoulos, 2006; Hemley 


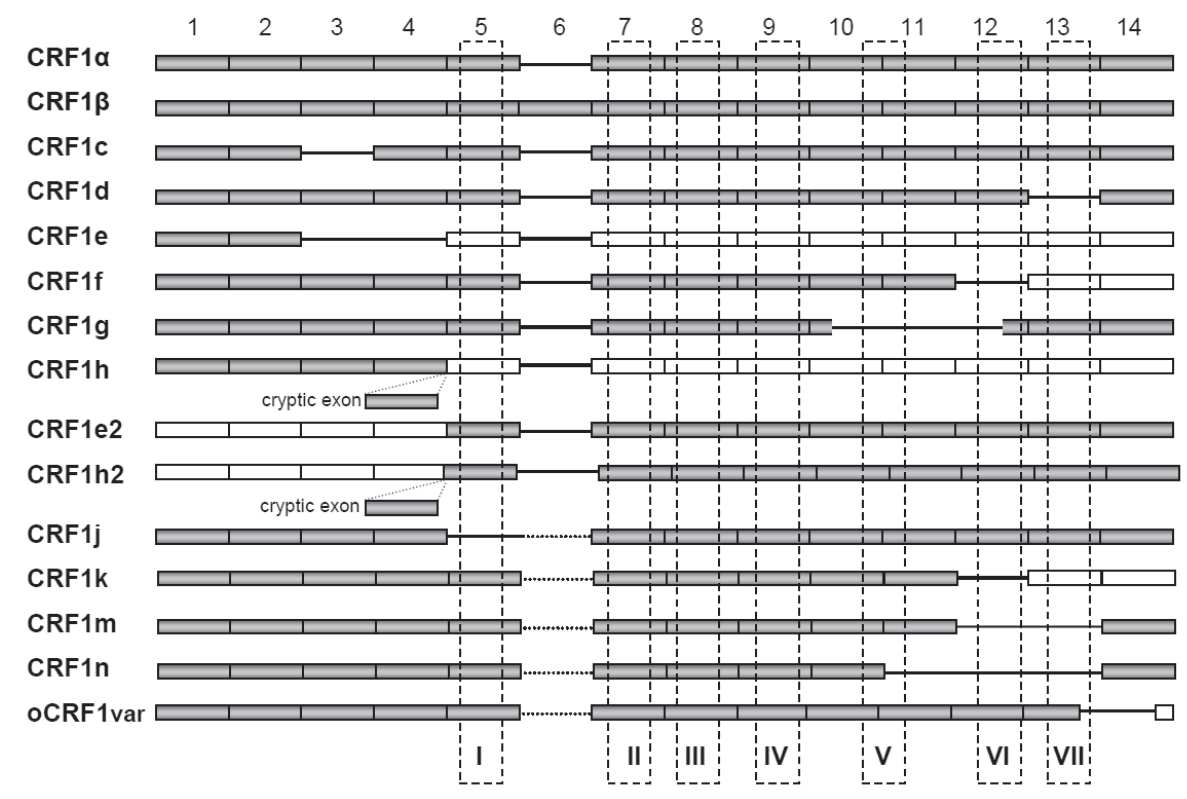

Figure 2. Schematic diagram of alternatively spliced isoforms of CRF1

CRF1 splicing variants differ in the number of exons (filed squares). Removed exons were shown as a line and exons with frame-shift as empty squares. Number of the exon (1 to 14) is indicated on the top. Names of CRF1 isoforms are indicated on the left. Isoforms $a, \beta$, $c, d, e, f, g$ and $h$ were detected in humans, mouse or hamster. CRF1e2 and CRF1h2 are theoretical alternative transcript from the same mRNA of CRF1e and $h$, respectively. Isoforms $j, k, m$ and $n$ were found only in hamster and isoform oCRF1var in sheep. Greek letters and doted boxes indicate transmembrane fragments I to VII. Modified after (Slominski et al., 2006b).

et al., 2007). CRF-related peptides share about $50 \%$ of sequence homology and they show unique affinities to CRF receptors (Dautzenberg et al., 2001).

\section{CRF receptors}

Human and all vertebrates express two types of CRF receptor - CRF1 and CRF2, also named: CRH-R1 and CRH-R2, or CRFR1 and CRFR2 (Perrin \& Vale, 1999; Hauger et al., 2006; Hillhouse \& Grammatopoulos, 2006; Slominski et al., 2006b). In the catfish a third member of the CRF receptor family was described as CRF3, which appears to be unique for this species (Arai et al., 2001). The CRF1 and CRF2 share about $70 \%$ of homology among different species and CRF3 shows higher homology to CRF1 than CRF2. CRF receptors seems to have originated from one ancestor gene, which was duplicated (in the case of the catfish triplicated) in order to differentiate responsiveness to the selected ligands. Accordingly, CRF1 has high affinity for CRF and UCN-I, and very low for UCN-II, while CRF2 possesses high affinity for UCN-I, UCN-II and a lower one for CRF (Dautzenberg et al., 2001; Hillhouse et al., 2002; Bale \& Vale, 2004; Hemley et al., 2007). CRF3 bound CRF with a 5-fold higher affinity than urotensin-I and sauvagine (Arai et al., 2001).

Although activation of CRF receptors is predominantly linked to up-regulation of cAMP through $\mathrm{G}_{\mathrm{sa}}$ subunit and adenylate cyclase pathway, the phenotypic outcome is different depending on anatomic location or cell type. On the central level, stimulation of CRF1 results in production of ACTH leading to arousal, somatic nervous system activation and under chronic conditions causes depression. On the other hand, activation of CRF2 leads to appetite suppression and acts like an antidepressant. Thus, CRF1 is implicated in normal response to stress, while CRF2 meditates fine-tuning of the stress response. Moreover, two CRF receptors have opposite functions in regulation of behavior with CRF1 mediating anxiogenic and CRF2 anxiolytic effects (Hillhouse et al., 2002; Bale \& Vale, 2004).

In order to facilitate such diverse functions a unique and functionally relevant pattern of expression of CRF receptors was described in the brain (Van Pett et al., 2000; Muller et al., 2001; Bale \& Vale, 2004; Hauger et al., 2006). In the human skin, CRF1 was found in all major cellular populations including keratinocytes, melanocytes and dermal papilla fibroblasts, while expression of CRF2 was limited to adnexal structures including hair follicular keratinocytes and pigmentary unit, papilla fibroblasts, sebaceous and eccrine glands (Slominski et al., 1995; 2000c; 2001; 2004a; 2007a; Pisarchik \& Slominski, 2001; Zouboulis et al., 2002; Ito et al., 2004; Kauser et al., 2006). Furthermore, expression of CRF receptor can be dynamic and change during development or be caused by physiological or pathological conditions (Slominski et al., 2001; Slominski, 2003; Hillhouse \& Grammatopoulos, 2006; Zmijewski \& Slominski, 2009a).

\section{ALTERNATIVE SPLICING OF CRF1 RECEPTOR REGULATES CRF SIGNALING}

Alternative splicing is a very common feature among GPCR receptors, especially in the B family (including Secretin and Adhesion receptors). For instance, in airway smooth muscle, of 353 expressed GPCR - 192 (including CRF1) had, on average, five different splicing variants (Einstein et al., 2008). Alternative splicing of CRF1 mRNA and function of isoforms in the brain structures and peripheral tissues including skin has been intensively studied during the last years (Chang et al., 1993; Pisarchik \& Slominski, 2001; 2002; Hillhouse \& Grammatopoulos, 2006; Slominski et al., 2006b; Nelson \& Challiss, 2007; Einstein et al., 2008). It was pos- 
tulated that alternative splicing can explain differential responsiveness of receptors to agonists/antagonists in tissue- or cell-specific manner (Pisarchik \& Slominski, 2001; 2004a; 2006b; Slominski, 2003; Hillhouse \& Grammatopoulos, 2006).

\section{Gene structure and properties of CRF1 receptor}

The genomic sequence for human CRF1 (CRHR1) was mapped to chromosome 17 (17q12-q22) (Polymeropoulos et al., 1995). The human CRF1 coding gene consists of 14 exons and 13 introns spanning about $20 \mathrm{~kb}$ and differs from the rat with 13 exons (Chen et al., 1993; Tsai-Morris et al., 1996; Sakai et al., 1998; Parham et al., 2004).

The general structure of CRF receptors is similar to other GPCRs and consists of an extracellular domain (ECD) or ligand binding domain encompassing the $\mathrm{N}$ terminal fragment and three extracellular coils (EC1-3); a seven $\alpha$-helical transmembrane domain (7TM) including three internal coils (IC1-3) and the C-terminus (Fig. 2 and 3). The most variable region of the CRF receptors is the N-terminal ECD with only $40 \%$ of homology between CRF1 and CRF2. The rest of the sequence is highly conserved with homology of $80 \%$ or greater for the 7TM domain and intracellular and extracellular loops. The third IC responsible for interaction with G-proteins was found to be identical for all CRFs (Hillhouse et al., 2002; Hemley et al., 2007).

The main isoform - CRF1 $\alpha$ is a 415 amino-acid protein and is coded by 13 of 14 exons of CRF1 premRNA (exon 6 is excluded). The first 23 amino acids form a signal peptide, which is subsequently processed (Perrin et al., 2001). The structure of ECD of CRF1 could be predicted based on the solved NMR structure of CRF2 $\beta$ (Perrin et al., 2006) and consists of two antiparallel $\beta$-sheets stabilized by three disulfide bonds between Cys30-Cys54, Cys44-Cys87 and Cys68-Cys102 forming a characteristic Sushi domain (Fig. 3). In addition, six or five N-glycosylation sides within the ECD of human or mouse CRF1 receptor were detected, respectively, but no O-glycosylation was observed (Assil \& Abou-Samra, 2001; Hofmann et al., 2001). PNGase F (peptide- $N^{4}-(N$-acetyl- $\beta$ glucosaminyl)asparagine amidase) treatment experiments additionally confirmed the presence of $\mathrm{N}$ glycan residues (Sydow et al., 1997; Slominski et al., 2007b; Zmijewski \& Slominski, 2009a). Glycosylation of CRF1 is thought to be responsible for proper function and trafficking of the receptor (Assil \& AbouSamra, 2001; Duvernay et al., 2005).

\section{Alternative splicing of CRF1 mRNA}

In human, expression of at least eight splicing variants of CRF1 has been detected so far, and several other isoforms have been detected in other organisms or could be theoretically predicted (Fig. 2) (Pisarchik \& Slominski, 2001; 2002; Hillhouse \& Grammatopoulos, 2006; Slominski et al., 2006b; 2007b).

Only one isoform, CRF1 $\beta$, also called pro-CRHR1 (Teli et al., 2008) is coded by all 14 exon, because in the sequence of other isoforms exon 6 is spliced out. CRF1 splicing variants could be divided into three groups: full-length receptors $(\mathrm{CRF} 1 \alpha, \beta)$, C-terminal, or ECD mutants (CRF1c and e) and isoforms with an impaired or missing 7TM domain (CRF1d, e, $\mathrm{f}, \mathrm{g}$ and $\mathrm{h}$ ). So-called "soluble" receptors (CRF1e, h) form a special subgroup of 7TM mutants lacking the

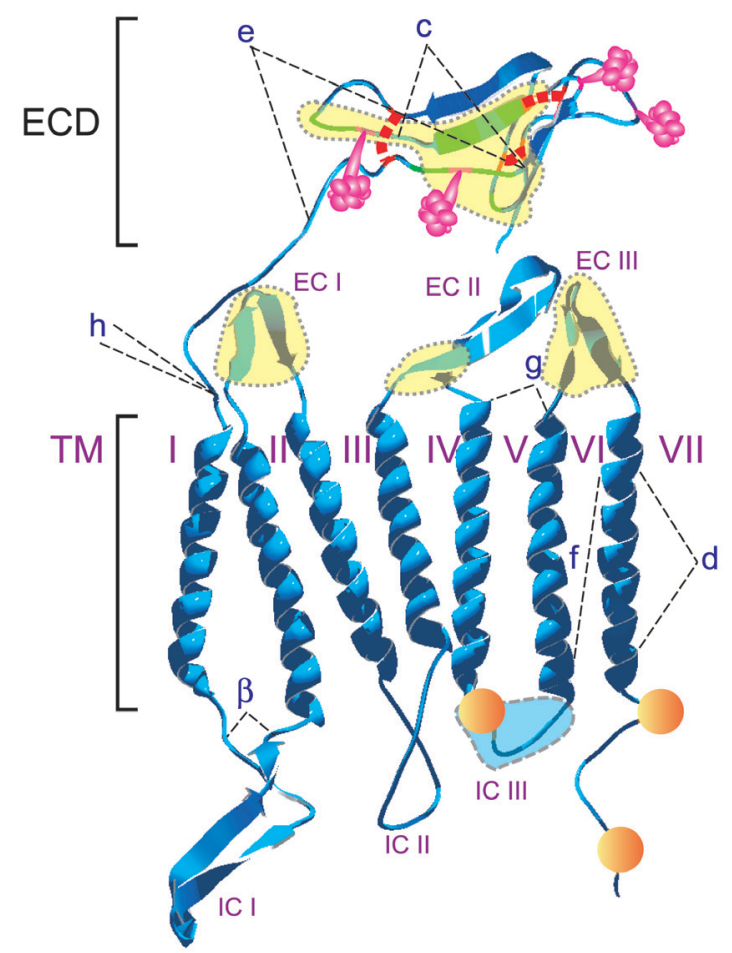

Figure 3. Model of CRF1 receptor and its splicing variants $(a, \beta$, c-h)

TM I-VII: transmembrane a-helical fragments, ECD: extracellular domain (ligand binding domain), EC I-III: extracellular coils, IC I-III: intracellular coils. Fragments removed by alternative splicing are shown by dotted lines. Fragments of ECD and EC III taking part in ligand binding are shown in yellow. Fragment of IC III responsible for G-protein binding shown in blue. Thick red dotted line: disulfide bonds, pink structures: glycosylation sides, orange balls: phosphorylation sides.

entire 7TM domain. The main isoform CRF $1 \alpha$ represents fully functional receptor and CRF1c has exon 3 spliced out. In isoform CRF1d exon 13 is missing. In the sequence of CRF1e exons: 3 and 4 are excluded, which causes a frameshift and introduction of a premature stop codon. CRF1f has exon 12 removed and in the sequence of CRF1g 27 base pairs of exon 10, the whole exon 11 and 28 base pairs of exon 12 are absent. CRF1h has an insertion of a cryptic exon between exons 4 and 5, resulting in a premature termination due to a frameshift (Pisarchik \& Slominski, 2001; 2002; Slominski et al., 2006b). In addition, mRNA of four unique isoforms (j, $\mathrm{k}, \mathrm{m}$ and $\mathrm{n}$ ) was detected in hamster (Pisarchik \& Slominski, 2002). Isoform CRF1j has a deletion of exon 5 resulting in a frameshift in exon 6 (in rodents CRF1 has only 13 exons and there is no equivalent of human exon 6). Other isoforms named CRF1k, $m$ and $\mathrm{n}$ have deletions within the 7TM domain as follows: exon 10; exon 11 and 12; or exons 10 to 12, respectively (Pisarchik \& Slominski, 2002).

The list of CRF1 splicing variants could be extended with theoretical isoforms coded by CRF1e and CRF1h mRNAs. These two isoforms would have alternative ATG start codons and code sole 7TM domains (Fig. 3) (Pisarchik \& Slominski, 2001; Slominski et al., 2006b; 2007b). This prediction is additionally supported by detection of a "headless" isoform of calcitonin receptor - another member of family B of GPCRs (Nag et al., 2007). 


\section{Expression of CRF1 isoforms}

Alternative splicing of mRNA encoding CRF1 was detected in multiple tissues and organs including: the brain (Ross et al., 1994), sheep pituitary (Myers et al., 1998), human corticotropic tumor derived from Cushing syndrome patient (Chen et al., 1993) and peripheral tissues including human skin (Pisarchik \& Slominski, 2001; 2002; Slominski et al., 2001; 2006a; 2006b; Zmijewski \& Slominski, 2009a), myometrium (Hillhouse \& Grammatopoulos, 2006; Jin et al., 2007; Markovic et al., 2007), adrenal glands (Sirianni et al., 2005) retinal pigment epithelium (Zmijewski et al., 2007), simian kidney cell line COS-7 (Slominski et al., 2007b), human adrenal glands (Sirianni et al., 2005), chorion trophoblasts (Gao et al., 2007) and placenta (Karteris et al., 1998). In addition hamster pituitary, eye, spleen, heart and skin was shown to express different CRF1 isoforms (Pisarchik \& Slominski, 2002). The efficient expression of alternatively spliced isoforms of CRF1 was confirmed by Western blotting detection of multiple bands with different molecular weights (Grammatopoulos et al., 1995; Sydow et al., 1997; Rivier et al., 2003; Pisarchik \& Slominski, 2004; Slominski et al., 2006a; 2007b; Zmijewski et al., 2007). The relatively high level of variability in molecular weight and the number of CRF1 receptors detected in different tissues, could not be the result of sole methodological differences (sensitivity of antibodies) or posttranslational modification, like proteolysis or glycosylation (for discussion see: Sydow et al., 1997; Slominski et al., 2006a). A variety of experimental studies on CRF1 mRNA and protein level revealed that organs, tissues and cell lines produce unique patters of receptor isoforms due to alternative processing of pre-mRNA (Fig. 2).

Although the detailed mechanism of CRF1 splicing remains unknown, there is growing evidence that this process is affected by many factors including UV irradiation (Pisarchik \& Slominski, 2001; Zmijewski \& Slominski, 2009a), cyclic adenosine monophosphate (cAMP), phorbol 12-myristate 13-acetatate (PMA) (Pisarchik \& Slominski, 2001), cell density (Zmijewski \& Slominski, 2009a), pregnancy (Jin et al., 2007) and onset of labor (Markovic et al., 2007).

Recent studies have suggested that alternative splicing of CRF1 might be independent from regulation of receptor expression (Markovic et al., 2007). Thus it can be proposed that splicing changes the pool of CRF1 $\alpha$ mRNA. Interestingly, an induction of CRF1 splicing by cAMP might suggest the presence of a negative feedback, where an elevated concentration of cAMP due to stimulation of the CRF $1 \alpha$ receptor would result in alternative splicing of the receptor, leading to at least partial inhibition of CRF signaling.

\section{REGULATION OF CRF SIGNALING BY CRF1 ISOFORMS}

Structure-function relationship plays a very important role in determination of activities of GPCRs and their isoforms. Detailed studies on CRF1 mutants and splicing variants revealed the functional importance for ECD and 7TM domains including external and internal coil regions and the C-terminus (Sydow et al., 1997; Hofmann et al., 2001; Perrin et al., 2001; Hillhouse \& Grammatopoulos, 2006; Slominski et al., 2006b; Markovic et al., 2008; Zmijewski \& Slominski, 2009a). As predicted, expression of ECD, alone, was sufficient for ligand binding, but the binding was enhanced by the presence of extracellular loops (Sydow et al., 1997). The 7TM domain is essential for proper signal transduction, resulting in activation of G-proteins and subsequent production of second messengers (cAMP, $\mathrm{IP}_{3}$ and $\mathrm{Ca}^{+2}$ ). IC-3 was shown to be involved in $\mathrm{G}$-protein interaction and the presence of the $\mathrm{C}$-terminus enhanced cAMP production (Grammatopoulos et al., 1999; Pisarchik \& Slominski, 2004). In addition to structural properties of CRF1 isoforms (and other GPCRs), their activity depends on their cellular localization. Specifically, CRF1 isoforms can be divided into three categories: membrane-bound, intracellular and extracellular (soluble) receptor forms (Slominski et al., 2006b).

It should be noted that a change in the receptor sequence by alternative splicing often results in frameshift and is responsible for premature termination of transcription. Such transcripts are prone to activate the nonsense-mediated mRNA decay mechanism (Lewis et al., 2003). Nevertheless, recent advances in receptor physiology suggest that these mRNA might encode proteins with modified but functional properties (Pisarchik \& Slominski, 2004; Hillhouse \& Grammatopoulos, 2006; Slominski et al., 2006b; Zmijewski \& Slominski, 2009a; 2009b).

\section{Classical pathway - CRF1a}

CRF1 $\alpha$ is the main and fully functional isoform of the receptor and the majority of publications concerning the CRF1 receptor (CRFR1, CRHR1, CRH-R1) refer to this isoform.

In the classical pathway, ligand binding to CRF1 leads to signal transduction across the cell membrane resulting in activation of heterotrimeric G-proteins (Fig. 4). Detailed studies have revealed that the CRF receptor interacts with several $G$-proteins with preference for $G_{\alpha s}$ and lower affinity for $G_{\alpha 0}, G_{\alpha q / 11}, G_{\alpha i}$ and $G_{\alpha z}\left(G_{r a m}-\right.$ matopoulos et al., 1999). Although, the primary target is represented by the activation of $\mathrm{G}_{\alpha \mathrm{s}}$ (adenylate cyclase (AC) - protein kinase A (PKA) pathway), it has to be noted that activation of specific $G$-proteins and signaling pathways can be tissue and cell type specific (Slominski et al., 2006a). It remains to be investigated if expression of alternative isoforms of CRF1 is responsible for modulation of affinity for $\mathrm{G}$-proteins or whether this process is regulated by other mechanisms including, e.g., phosphorylation of the receptor.

The increase in concentration of secondary messengers (cAMP, $\mathrm{IP}_{3}$ and $\mathrm{Ca}^{2+}$ ) in cells triggered by $\mathrm{CRF} 1 \alpha$ ligands, results in activation of multiple transcriptional factors including $\mathrm{CREB}, \mathrm{AP}-1, \mathrm{NF}-x \mathrm{~B}$, and the calcium response element (CARE) (Fig. 4) (Fazal et al., 1998; Wiesner et al., 2003; Pisarchik \& Slominski, 2004; Zbytek et al., 2004; 2005; Zbytek \& Slominski, 2005; Slominski et al., 2006b; Zmijewski \& Slominski, 2009a; 2009b). The CRE element was shown to be stimulated through the signaling cascade involving $G_{\alpha s}$-mediated activation of adenylate cyclase (AC), cAMP accumulation, PKA activation and CREB phosphorylation at Ser-133 (Fig. 4) (Pisarchik \& Slominski, 2001; Eckart et al., 2002; Slominski et al., 2006b). CRF stimulation also results in $\mathrm{G}_{\alpha \mathrm{c}}$-protein dependent activation of phospholipase $\mathrm{C}$ (PLC), leading to $\mathrm{IP}_{3}$ accumulation. Subsequent activation of PKC results in an indirect stimulation of expression and accumulation of AP-1 transcription factor in the nucleus (Hofmann et al., 2001; Eckart et al., 2002; Pisarchik \& Slominski, 2004; Slominski et al., 2006b). $\mathrm{CRF}$ and urocortin stimulation in the skin results in an increase of intracellular $\mathrm{Ca}^{2+}$ concentration via a dual mechanism which involves release of $\mathrm{Ca}^{2+}$ from intracel- 


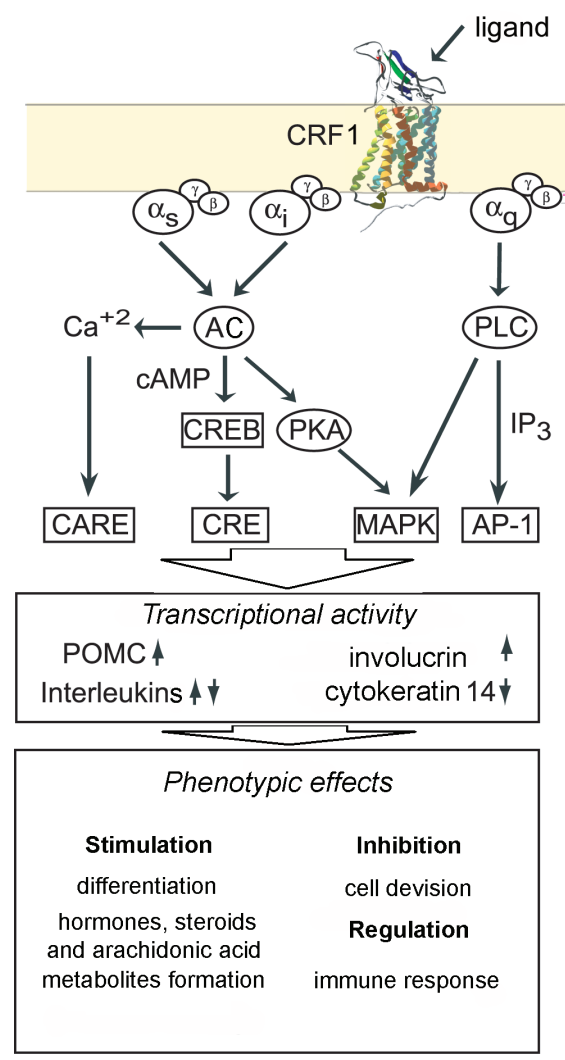

Figure 4. Activation of intracellular signaling pathways by stimulation of CRF1 receptor

Ligand binding to CRF1 receptor activates at least three $G$ subunits $\left(a_{s}, a_{i}\right.$ and $\left.a_{f}\right)$ of $G$-protein resulting in stimulation CAMP production by adenylate cyclase (AC) with subsequent CAMP-induced phosphorylation of CREB and activation of the CAMP-responsive element (CRE). Mobilization of calcium $\left(\mathrm{Ca}^{+2}\right)$ results in activation of the calcium-responsive element (CARE). Activation of AP-1 can also trigger the mitogen-activated protein kinase (MAPK) pathway through protein kinase $A$ (PKA). In addition, a -mediated stimulation of phospholipase $C$ results in $\mathrm{IP}_{3}$-driven activation of activator protein $1(\mathrm{AP}-1)$ dependent promoters. Downstream signaling from CRF1 receptor regulates expression of several genes including POMC, several interleukins, involucrine and cytokeratin 14. The phenotypic effects of stimulation include: stimulation of differentiation, steroidogenesis, melanogenesis and release of arachidonic acid. CRF inhibits cell division and regulates immune response. See text and citations within for details.

lular stores and increases $\mathrm{Ca}^{2+}$ influx by the opening of voltage-activated $\mathrm{Ca}^{2+}$ ion channels (inhibited by EGTA, d-cis-diltiazem and verapamil) (Fazal et al., 1998; Slominski et al., 1999; Wiesner et al., 2003). CRF can also activate CARE and this activation is mediated thought the CRF1 $\alpha$ isoform as shown in HaCaT keratinocytes (Pisarchik \& Slominski, 2001; Zmijewski \& Slominski, 2009a), COS-7 cells (Slominski et al., 2007b) or AtT-20 cells (Zmijewski \& Slominski, 2009b).

The activation of multiple signaling pathways is responsible for several phenotypic manifestations of CRF1 $\alpha$ stimulation. Besides classic stimulation of POMC expression (Fig. 1) activation of CRF1 $\alpha$ receptor influences cell proliferation and differentiation (Fig. 4) (Slominski et al., 2000c; 2006a; 2006b; Kauser et al., 2006; Conn et al., 2007; Ganceviciene et al., 2009). Moreover, CRF and its receptors are important for immunomodulation (Karalis et al., 1991; Slominski, 2003; Theoharides et al., 2004; Arck et al., 2006; Slominski et al., 2006a; Zbytek \& Slominski, 2007; Paschos et al., 2009). Differentiation program of the keratinocytes has been linked to activation of AP-1 family members such as JunB, JunD and Fra1 (Eckert et al., 2004; Zbytek et al., 2005; Zbytek \& Slominski, 2005). Activation of CRF1 receptor modulates the activity of $\mathrm{NF}-x \mathrm{~B}$ - the main regulator of cell viability, differentiation and cytokine production (Zbytek et al., 2003; 2004; 2006a; Slominski et al., 2006b). This process was studied in-depth using epidermal skin cells (Zbytek et al., 2003; 2004; 2006a) and it was postulated that CRF and its receptor play a dual role in regulation of $\mathrm{NF}-x \mathrm{~B}$ activity depending on the prevailing environmental context (Paez Pereda et al., 1995; Slominski, 2003; Slominski et al., 2006b). Depending on conditions but according to the classic model (Baeuerle \& Baltimore, 1988) activation of $\mathrm{CRF} 1 \alpha$ receptor in the skin influences stability of $\mathrm{I} x \mathrm{~B}-\alpha$, which serves as a negative regulator of $\mathrm{NF}-x \mathrm{~B}$ (Slominski, 2003; Zbytek et al., 2003; 2004; Slominski et al., 2006b). Other investigators also reported, either stimulatory or inhibitory effects of CRF on immunocompetent skin cells (Quevedo et al., 2001; Zbytek et al., 2003; 2004), and CRFdependent regulation of NF-xB activity in different experimental models (Lezoualc'h et al., 2000; Zhao \& Karalis, 2002). CRF-driven activation of $\mathrm{NF}-x \mathrm{~B}$ pathway was also observed in normal keratinocytes (Zbytek et al., 2004) but in contrast stimulation of normal melanocytes with CRF had the inhibitory effect on the NF- $x$ B activity (Zbytek et al., 2006a).

Thus, the activation of secondary messengers and phenotypic effects of CRF1 $\alpha$ stimulation is cell type-dependent and regulated by external and internal factors. It is tempting to conclude that such a diversity is regulated at least in part by expression of several CRF1 isoforms. Moreover, recent studies have revealed that alternative splicing is a dynamic process of adaptation to the changing environment (Markovic et al., 2007; Zmijewski \& Slominski, 2009a). Unfortunately, there is a shortage of information on the phenotypic consequences of alternative splicing of CRF1 which might lead to wrong assumption concerning CRF signaling in given cellular model.

\section{Membrane-bound isoform - CRF1 $\beta$}

CRF1 $\beta$ is sometimes referred to as pro-CRF1, because it is encoded by all the 14 exons, including exon 6 spliced out from all the other known isoforms (Chen et al., 1993; Xiong et al., 1995). Integration of the 29-amino-acid fragment encoded by exon 6 into first intracellular coil of CRF1 only slightly inhibits substrate-binding properties of the receptor $(2.1 \times)$, but cAMP production was found to be impaired $(100 \times$ decrease) (Xiong et al., 1995). Recent studies have shown that a positively charged fragment (F170-R174) of the CRF1 $\beta$ insert is responsible for inhibition of cAMP response (Teli et al., 2008). Furthermore, retention of exon 6 also increases responsiveness to PKC-induced phosphorylation and results in premature desensitization of signaling and internalization of the receptor (Markovic et al., 2006). Thus, despite of proper cell membrane localization CRF1 $\beta$ and possession of all the structural features of the native receptor, CRF signaling through CRF1 $\beta$ is impaired.

\section{Membrane bound isoform - CRF1c}

CRF1c, the other example of a CRF1 isoform possesses an intact 7TM domain (Ross et al., 1994), which indicates proper cell membrane localization (Slominski et al., 2006b), and this has been recently confirmed experimentally (Zmijewski \& Slominski, 2009a; 2009b). On the other hand, a deletion of 40 amino acids encoded by exon 3 removes the central part of ECD including 
three out of six cysteines. These residues are crucial in formation of disulfide bridges essential for stability of the ECD domain (Fig. 3). Thus, in spite of the proper membrane localization, CRF1c expressed in the kidney cell line COS-1, failed to bind agonists (125I-oCRF) (Ross et al., 1994). Elevation of the intracellular level of cAMP was observed only after stimulation with a high concentration of human CRF (Ross et al., 1994; Grammatopoulos et al., 2000). It has to be noted that detection of CRF stimulated accumulation of cAMP in cells overexpressing CRF1c could be at least partially explained by endogenous expression of CRF1 shown in the another fibroblast-like kidney cell line COS-7 (Slominski et al., 2007b). Moreover, CRF and urocortin were not able to stimulate CRF1c mediated $\mathrm{IP}_{3}$ production, MAPK phosphorylation or CRE activation in human embryonic kidney line (HEK 293) overexpressing CRF1c (Grammatopoulos et al., 2000; Markovic et al., 2008).

\section{CRF1 isoforms with impaired 7TM domain}

At least 5 human isoforms of CRF1 receptor (CRF1d, $\mathrm{e}, \mathrm{f}, \mathrm{g}$ and $\mathrm{h}$ ) have alterations within the 7TM domain (Pisarchik \& Slominski, 2001; Hillhouse \& Grammatopoulos, 2006; Slominski et al., 2006b). In hamster, in addition to human-like isoforms CRF1e, $f$ and $h$, mRNAs of 4 unique CRF1 splicing variants (CRF1j, k, 1 and $\mathrm{m}$ ) were detected (Pisarchik \& Slominski, 2002). 7TM variants represent variety of single or multiple exon deletions with or without frameshift (Fig. 2) (Pisarchik \& Slominski, 2002; Hillhouse \& Grammatopoulos, 2006; Slominski et al., 2006b). In addition, a CRF1 isoform named oCRF1var with a deletion of 34 amino acids forming the last $\alpha$-helical fragment of 7TM domain and a part of the C-terminus was described in sheep (Myers et al., 1998). Additional, so called "soluble" isoforms (CRF1e, $j$ and h) lack the entire 7TM domain and will be described in the next chapter.

CRF1d with a characteristic deletion of a 14-amino-acid fragment of the 7TM domain coded by exon 12, was first described by the Gramatopoulos group (Grammatopoulos et al., 1999; Hillhouse \& Grammatopoulos, 2006). The deletion of a fragment of the seventh transmembrane $\alpha$-helix did not result in a decrease in substrate binding affinity, when compared with CRF1 $\alpha$. However, distortion of the 7TM domain inhibits interaction of the receptor with G-proteins $\left(G_{\alpha s}, G_{\alpha 0}, G_{\alpha q}\right.$ and $\left.G_{\alpha i}\right)$ and results in subsequent inhibition of downstream signaling, as judged by an at least 10-fold decrease in cAMP synthesis and total inhibition of $\mathrm{IP}_{3}$ production (Grammatopoulos et al., 1999). As a consequence, inhibition of activation of cAMP or $\mathrm{IP}_{3}$ response elements (CRE and AP-1) was observed in cells overexpressing CRF1d (Zmijewski \& Slominski, 2009a; 2009b). In SKMEL-188 melanoma cells, which only express the CRF1d isoform, the lack of coupling to cAMP with overt stimulation of $\mathrm{Ca}^{2+}$ flux suggest that the CRF1d signal transduction pathway is only coupled to either voltage-activated $\mathrm{Ca}^{2+}$ ion channels or PLC (Slominski et al., 2006a; Zmijewski \& Slominski, 2009b). Ovine CRF1var was also shown to bind oCRF (ovine CRF) with comparable affinity to the native receptor, but oCRF-stimulated accumulation of cAMP and internalization of the receptor was impaired (Myers et al., 1998). Inhibition of downstream signaling as measured by cAMP accumulation or activation of CRE, CARE, AP-1 transcription elements was also observed in various cells overexpressing human isoforms CRF1f and g (Pisarchik \& Slominski, 2004; Zmijewski \& Slominski, 2009a; 2009b). Thus, it is postulated that distortion within the 7TM domain resulting from alternative splicing of CRF1 mRNA does not significantly influence an affinity for ligands, but affects binding to Gprotein and, consequently downstream signaling through the receptor is impaired.

Recent studies have shown that overexpression of CRF1d in contrast to CRF1 $\alpha$ resulted in intracellular accumulation of this 7TM mutant (Markovic et al., 2008; Zmijewski \& Slominski, 2009a; 2009b). Intracellularly, CRF1d was found to be associated with the endoplasmic reticulum and CRF1f and $g$ with Golgi cisterns in human HaCaT keratinocytes (Zmijewski \& Slominski, 2009a). These findings might explain high intracellular CRF1 immunoreactivity in human skin tissue and cell lines or uterine smooth muscle cells, known to express multiple CRF1 isoforms including 7TM mutants (Slominski et al., 2006a; Markovic et al., 2007; Zmijewski \& Slominski, 2009a).

A recent study by Markovic and collaborators (Markovic et al., 2008) showed that cassette G356-F358 within the seventh transmembrane helix of CRF1 $\alpha$ (exon 13) is crucial for membrane localization of the receptor (Figs. 2 and 3). Deletion or misplacement of this fragment is characteristic for all 7TM isoforms of CRF1 (Figs. 2 and 3). Interestingly, CRF1d and a calcitonin receptor splicing variant (CRTDe13) have an analogous exclusion of exon 13 with similar physiological consequences (Shyu et al., 1996; Seck et al., 2003; 2005). Moreover, co-expression of CRF1 $\alpha$ with $\mathrm{CRF} 1 \mathrm{~d}, \mathrm{f}$ or $\mathrm{g}$ results in retention of both isoforms inside the cell (Zmijewski \& Slominski, 2009a; 2009b). Intracellular retention of CRF1 isoforms is most likely associated with their oligomerization (Kraetke et al., 2005; Mikhailova et al., 2007; Markovic et al., 2008; Zmijewski \& Slominski, 2009a; $2009 \mathrm{~b})$. Thus, it could be postulated that distortion of the 7TM domain of CRF1 receptor (and other GPCRs) results in at least partial retention of the reception in the cell, impairs G-protein binding and signal transduction despite only slightly altered ligand binding. In addition an intracellular localization sequesters the receptor and its homo- and heterodimers prevents an interaction with extracellular substrates.

\section{Soluble isoforms}

At least two human, mouse and three hamster CRF1 isoforms lack entire 7TM domains, due to alternative splicing (Pisarchik \& Slominski, 2001; 2002). In an analogy to artificial ECD models: mNT-CRF1 and sCRFR2 $\alpha$, they are called "soluble" forms (Perrin et al., 2001; Pisarchik \& Slominski, 2001; Chen et al., 2005).

CRF1h (human, mouse and hamster) similarly to CRF1j (only found in hamster) are encoded by exons $1-4$ of full length CRF1. Deletion of exon 5 results in a frameshift and introduction of a premature stop codon. In an addition CRF1h is encoded by a cryptic exon immediately after exon 4 (Pisarchik \& Slominski, 2001; Slominski et al., 2006b). Similarly to artificial constructs - mNT-CRFR1 (Perrin et al., 2001) and sCRF2 $\alpha$ (Chen et al., 2005) the soluble isoform CRF1h may be capable of binding the ligands. This is in contrast to CRF1e isoform missing most of its ECD (Figs. 2 and 3) (Slominski et al., 2006b). Although activity of different artificial models of ECD was proven, their ability to bind substrates was found to be lower when compared to full length receptor. For instance, rat rCRFR1-NTKif construct (rat model of ECD), specifically bound to arrestin and rat $\mathrm{UCN}$, but the affinity was found to be 10-folds lower than for full-length rat CRF1 (Hofmann et 
al., 2001). Similarly, binding of several ligands (rUCN-1, mUCN-2, mUCN-3, r/hCRF) to the ECD1-CRFR2 $\beta$ construct (containing ECD of CRF $2 \beta$ receptor) was 5 to 10 times lower when compared to full length CRF2 $\beta$ expressed in Chinese hamster ovary cell line (CHO). The same study revealed that ECD1-CRFR2 $\beta$ soluble receptor was not able to bind sauvagine, suggesting that another part of CRF2 receptor was specifically responsible for sauvagine binding (Perrin et al., 2003). Other experiments showed involvement of extracellular coil EC-3 in ligand binding and this finding might partially explain lower substrate affinity of soluble CRF receptor isoforms containing exclusively ECD (Sydow et al., 1997; Gkountelias et al., 2009).

Overexpression of CRF1h in immortalized human $\mathrm{HaCa} \mathrm{T}$ keratinocytes results in co-localization with endoplasmic reticulum and cytoplasm, but not with cell membrane or CRF1 $\alpha$ (Zmijewski \& Slominski, 2009a). Interestingly, both CRF1h and to a lower degree CRF1e (Zmijewski \& Slominski, 2009a), similarly to mNTCRFR1 (Perrin et al., 2001) and sCRF2 $\alpha$ (Chen et al., 2005), could be released to the medium. Thus, localization of soluble isoforms might determine their function. Co-expression of CRF1h with CRF1 $\alpha$ increased in production of cAMP in COS-7 cells (Pisarchik \& Slominski, 2004), but caused decrease or had no influence on the activity of cAMP or AP-1 responsive elements in $\mathrm{Ha}-$ CaT keratinocytes (Zmijewski \& Slominski, 2009a) and AtT-20 pituitary cells (Zmijewski \& Slominski, 2009b), suggesting involvement of other CRF1 isoforms or/and cell specific factors. Potential activity of secreted soluble isoforms was shown in a "media exchange" experiment performed on AtT-20 cells overexpressing CRF1 isoforms. Presence of CRF1h and to a lesser extend CRF1e in culture medium partially inhibited stimulation of CRF1 $\alpha$ by CRF in AtT-20 corticotrophic cells (Zmijewski \& Slominski, 2009b). Thus these isoforms, under certain conditions, could act as soluble decoy receptors, as previously suggested (Pisarchik \& Slominski, 2004; Chen et al., 2005).

CRF1e protein has only 40 amino acids of native protein including a signal peptide of 23 amino acids. The major part of ECD responsible for ligand binding is missing and the remaining 104 amino acids incorporated to the sequence due to frameshift have no homology to any known protein (Pisarchik \& Slominski, 2001). In addition, it seems that CRF1e mRNA, or/and protein is not stable because GFP signal from fusion receptor CRF1e-GFP fades away a few days after transfection, while overexpression of other fusion constructs containing CRF1 isoforms resulted in stable fluorescence for more than a week (Zmijewski \& Slominski, 2009a). CRF1e was equally distributed within the cells when overexpressed in HaCaT keratinocytes or AtT-20 pituitary cells. In addition, CRF1e was the sole receptor isoform found in the nucleus. Co-expression of CRF1e and CRF $1 \alpha$ did not result in co-localization of both isoforms, but unexpected intracellular aggregation of CRF1 $\alpha$ was observed (Zmijewski \& Slominski, 2009a). Further studies are necessary to establish a mechanism for those phenomena. Transient transfection with CRF1e did not result in activation of CRF-driven signaling in cells of various origins (Pisarchik \& Slominski, 2004; Zmijewski \& Slominski, 2009a; 2009b). It is possible that accumulation of CRF1e mRNA can lower the pull of CRF1 $\alpha$ mRNA spliced out from common precursor, having a negative effect on final CRF1 $\alpha$ expression. This hypothesis requires additional experimental validation.

\section{ROLE OF ALTERNATIVE SPLICING}

It has been widely accepted that the expression of certain types of GPCR receptors does not fully explain the variety of cellular responses after stimulation with selective agonists. Many factors could be involved in such regulation, including posttranslational modification, receptor oligomerization, constitutive activation or presence of cell specific modifiers (Nelson \& Challiss, 2007; Zmijewski \& Slominski, 2009a).

Alternative splicing is a common feature of at least $70 \%$ of human genes being responsible for increased functional capacity of the human genome. Many GPCRs including CRF1 and other members of the B1 family (secretins) have several variants generated by alternative splicing (Einstein et al., 2008). Although the detailed mechanism of alternative splicing has been studied for many years, its function is not well understood, especially in the case of GPCRs (Minneman, 2001; Bjarnadottir et al., 2007).

Expression of the majority of alternative spliced variants of CRF1 results in a dominant negative phenotype, or at least modulatory responses (Fig. 5). Moreover, alternative splicing of CRF1 is not only tissue- or organ-specific, but it is also tightly regulated by intra and extracellular factors (Hillhouse \& Grammatopoulos, 2006; Slominski et al., 2006b; Zmijewski \& Slominski, 2009a). In addition, alternatively spliced mRNA of CRF1 isoforms may undergo fast mRNA decay process (nonsense-mediated decay - NMD). This process may be linked to the presence of premature termination codon introduced by alternative splicing (Lewis et al., 2003; Amrani et al., 2006). Several CFR1 isoforms including CRF1e, f, h and $\mathrm{k}$, possess alternative, premature stop codons introduced by alternative splicing (Fig. 2). It seems unlikely that such a complex system, conserved in evolution is just a random noise of the spliceosome.

There is growing evidence that alternative splicing of CRF1 pre-mRNA is responsible for modulation of CRF signaling. In the current model, isoform CRF1 $\alpha$ has a dominant role as a fully functional receptor and the remaining isoforms regulate its activity (Fig. 5). The first and obvious consequence of alternative splicing of CRF1 mRNA is lowering of the pool of mRNA of native receptor (CRF1 $\alpha)$, which may potentially inhibit of CRF signaling. Another function of CRF1 isoforms may be formation of receptor oligomers (dimers) (Sirianni et al., 2005; Gurevich \& Gurevich, 2008). Although dimerization does not appear to be essential for ligand binding (Kraetke et al., 2005), CRF1 was found to form homo- and heterooligomers by several groups (Kraetke et al., 2005; Mikhailova et al., 2007; Young et al., 2007; Zmijewski \& Slominski, 2009a). High molecular complexes containing CRF1 isoforms were stable under mild denaturating conditions during SDS/PAGE separation (Sydow et al., 1997; Pisarchik \& Slominski, 2004; Slominski et al., 2007b; Zmijewski et al., 2007; Zmijewski \& Slominski, 2009a). Interestingly, such complexes are sensitive to deglycosylation and reducing agents (dithiothreitol) suggesting a role of $\mathrm{N}$-glycans and disulfide bonds in the stability of CRF1 ternary complexes (Zmijewski \& Slominski, 2009a). The formation of homo- and heterodimers of CRF1 isoforms might also regulate of CRF $1 \alpha$ localization and activity. For example, heterooligomerization could explain intracellular co-localization of CRF1 $\alpha$ with isoforms with impaired 7TM 


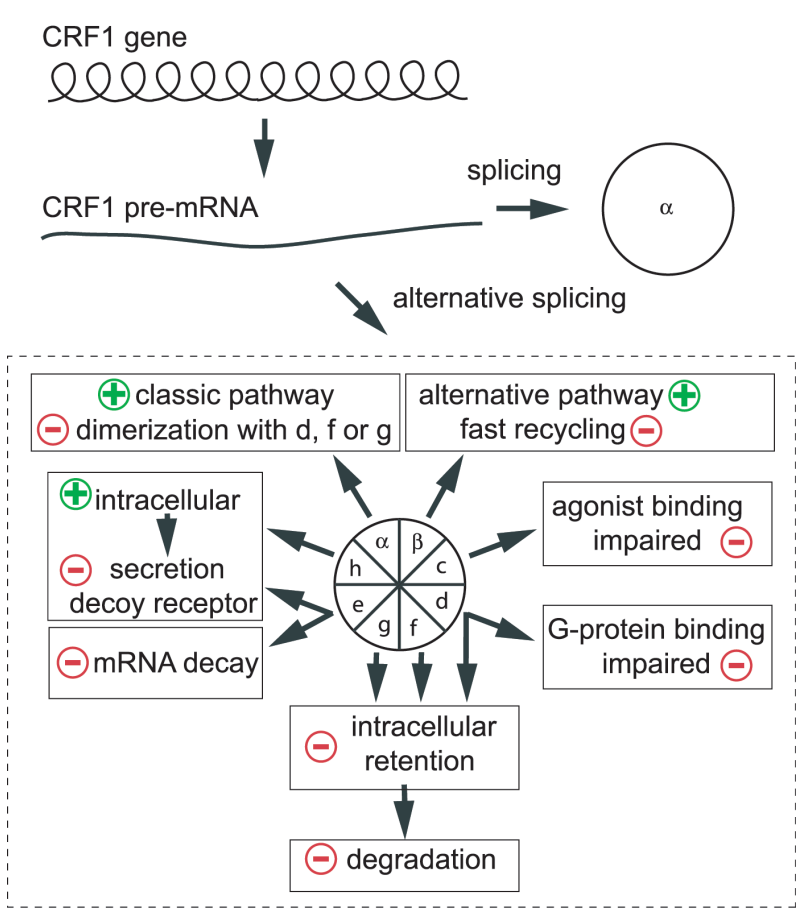

Figure 5. Regulation of CRF signaling by CRF1 isoforms CRF1 gene contains 14 exons and only one isoform of receptorCRF1 $\beta$ (also called pro-CRF1) is coded by all exons. CRF1 transcript is also subjected to alternative splicing resulting in at least 8 isoforms. Recent studies showed that expression and/or co-expression of CRF1 isoforms is responsible for modulation of CRF1 signaling. Plus indicates stimulation of downsteam signaling by the classic pathway (CRF1a) or alternative pathway (CRF1 $\beta$ ). Soluble isoforms (CRF1e and $h$ ) were also found to stimulate CRF signaling when co-expressed with CRF1a. Minus indicates inhibition of CRF signaling on different levels including: fast mRNA decay (CRF1e), dimerization and subsequent intercellular retention resulting in most probable premature receptor degradation (CRF1a with CRF1d, CRFf or CRFg), decoy receptor mechanism (CRF1h and e when secreted), agonist binding impairment (CRF1C) or G-protein wbinding inhibition (CRF1d). See text for details and citations.

domains $(\mathrm{CRF} 1 \mathrm{~d}, \mathrm{f}$ and $\mathrm{g})$ and resulting partial inhibition of CRF signaling. Recently a similar interaction was observed for two isoforms of CRF2, e.g., CRF2 $\beta$, and (iv)-mCRF2 $\beta$ (Sztainberg et al., 2009). Moreover, CRF1 $\beta$ was found to be rapidly internalized after formation of heterodimers with CRF1 $\alpha$. Therefore, we postulated that heterooligomerization of CRF1 isoforms can diversify the repertoire of functional CRF1 receptors and/or modulate CRF signaling (Slominski et al., 2006b; Markovic et al., 2008; Zmijewski \& Slominski, 2009a; 2009b).

Soluble isoforms of CRF1 (CRF1e, h) are similar to mNT-CRFR1 (Perrin et al., 2001) and sCRF2 $\alpha$ (Chen et al., 2005) and their biological activities have already been demonstrated. The mechanism of extracellular activity of soluble isoforms should be similar to CRF binding protein (CRF-BP), which serves as an extracellular binding protein that resembles decoy receptors (Chen et al., 2005).

It must be also mentioned that the activity of the receptors from class B of GPCR can be modulated by several other factors, including receptor activity-modifying proteins (RAMPs) (Sexton et al., 2006), $\beta$-arrestins (Holmes et al., 2006), G protein-coupled receptor kinases (GRK1-3) or Rab GTPases (Miller et al., 2007).
CRF1 IN HUMAN DISEASES, ALTERNATIVE SPLICING AS A POSSIBLE TARGET

GPCRs are a target for $40-50 \%$ of all marketed drugs (Hemley et al., 2007) and CRF1 antagonists and agonists have potential benefits in the therapy of several human pathologies. The agonists of CRF1 receptor with low hypotensive activity such as [D-Glu20]-CRH may be used in therapy of malignant melanoma as their antiproliferative activity was shown in vivo and in an animal model (Carlson et al., 2001). Human and rodent skin cancer cell lines including melanomas (Pisarchik \& Slominski, 2001; 2002), squamous cell carcinomas and basal cell carcinomas (Pisarchik \& Slominski, 2001) express different patterns of CRF1 isoforms, thus alternative splicing of CRF1 may play an important role in sensitivity of cancer cells to CRF and its analogues. In general skin cancer cell lines express multiple isoforms of CRF1 receptor. It has to be stressed that the effect of CRF and CRF-related peptides strongly depends on cellular context as has been shown for different skin cells (Zbytek et al., 2003; 2004; 2005; 2006a; 2006b; Slominski et al., 1999; 2000c; 2006b; 2007a).

Single nucleotide polymorphism (SNP) another factor, which might also influence alternative splicing of CRF1 mRNA. This phenomenon is of particular interest, because CRF1 SNPs have been associated with many human conditions, including: depression (Liu et al., 2006), stress, alcohol abuse (Blomeyer et al., 2008; Schmid et al., 2009), suicidal tendencies (Wasserman et al., 2008), infection susceptibility, asthma (Lima et al., 2009) and bone density (Jones et al., 2008). Thus, in-depth investigation of CFR1 splicing in the context of CRF1 SNPs might bring some mechanistic explanation for genetically determined changes in CRF1 receptor activity.

Several antagonists of CRF1 receptors have been studied including CRF analogues ( $\alpha$-helical CRF and other compounds see: Wei \& Thomas, 1994; Rivier et al., 2002; 2007) and antalarmin (non-peptide CRF1 antagonist) (Webster et al., 1996; Deak et al., 1999) as well several other agonists and antagonists of CRF1 and CRF2 (see for review: Gulyas et al., 1995; Reyes et al., 2001). Antalarmin and its derivatives, as the potent CRF1 antagonists have been successfully used in animal models of anxiety disorders, alcohol and drug addiction (Zoumakis et al., 2006), inflammatory bowel syndrome (Paschos et al., 2009).

Certaily, detailed studies on CRF1 alternative splicing and possible influence of local environment are required in order to assess potential benefits of CRF1 agonist/ antagonist therapy (Wei \& Slominski, 2002; Vale, 2004; Pisarchik \& Slominski, 2006). On the other hand modulation of CRF1 activity by an alternative splicing may represent a promising strategy to regulate sensitivity of cells to CRF1 agonists or antagonists. There are several factors and drugs with proven influence on alternative splicing (for review see: Sumanasekera et al., 2008). Surprisingly, many anticancer drugs including daunorubicin and cisplatin can also affect alternative splicing as shown for $B c l-X$ and other human apoptotic genes (Shkreta et al., 2008). Thus, selective modulation of CRF1 splicing is feasible. For example, splice-switching oligonucleotides (for recent review see: Bauman et al., 2009) or chemically modified antisense oligonucleotides (Kole et al., 2004) could be used to change the pattern of expression of CRF1 isoforms in order to sensitize or desensitize cells to CRF1 agonists. Specifically, induction of CRF1 variants $\mathrm{c}, \mathrm{d}$, f or $\mathrm{g}$ by CRF1-targeted splice-switching 
oligonucleotides might be alternative to antalarmin in treatment of anxiety disorders, alcohol and drug addiction, inflammatory bowel syndrome. On the other hand, it is possible that directing alternative splicing towards expression of the CRF1 $\alpha$ isoform may sensitize cells to CRF-driven inhibition of cancer cell proliferation (for example, melanoma). Thus, induced modulation of alternative splicing of CRF1 may represent a dawn of new therapeutic strategies targeting a variety of diseases (Pisarchik \& Slominski, 2006).

\section{CONCLUSION}

There is growing evidence that alternative splicing of CRF1 receptor represents an additional level of regulation of central and local responses to stress via the HPA axis. Expression of several CRF1 isoforms depends on a variety of external and internal factors and appears to be responsible for regulation of activity of CRF signaling. Thus, the alternative splicing of CRF1 (and other GPCRs) is not only a very important and complex regulatory mechanism but may also represent a novel pharmacological target in therapy of various disorders (Wei \& Slominski, 2002; Hillhouse \& Grammatopoulos, 2006; Pisarchik \& Slominski, 2006; Slominski et al., 2006b; Einstein et al., 2008; Wasserman et al., 2008; Lima et al., 2009; Sztainberg et al., 2009; Zmijewski \& Slominski, 2009a).

\section{Acknowledgements}

ATS is supported by NIH grant R01A052190 and NSF grant \#0918934.

\section{REFERENCES}

Abdel-Malek Z, Swope VB, Suzuki I, Akcali C, Harriger MD, Boyce ST, Urabe K, Hearing VJ (1995) Mitogenic and melanogenic stimulation of normal human melanocytes by melanotropic peptides. Proc Natl Acad Sci USA 92: 1789-1793.

Abdel-Malek Z, Scott MC, Suzuki I, Tada A, Im S, Lamoreux L, Ito S, Barsh G, Hearing VJ (2000) The melanocortin-1 receptor is a key regulator of human cutaneous pigmentation. Pigment Cell Res $\mathbf{1 3}$ (Suppl 8): 156-162.

Amrani N, Sachs MS, Jacobson A (2006) Early nonsense: mRNA decay solves a translational problem. Nat Rev Mol Cell Biol 7: 415-425.

Arai M, Assil IQ, Abou-Samra AB (2001) Characterization of three corticotropin-releasing factor receptors in catfish: a novel third receptor is predominantly expressed in pituitary and urophysis. Endocrinology 142: 446-454.

Arck P, Paus R (2006) From the brain-skin connection: the neuroendocrine-immune misalliance of stress and itch. Neuroimmunomodulation 13: 347-356.

Arck PC, Slominski A, Theoharides TC, Peters EM, Paus R (2006) Neuroimmunology of stress: skin takes center stage. J Invest Dermatol 126: 1697-1704.

Asakura H, Zwain IH, Yen SS (1997) Expression of genes encoding corticotropin-releasing factor (CRF), type $1 \mathrm{CRF}$ receptor, and CRF-binding protein and localization of the gene products in the human ovary. I Clin Endocrinol Metab 82: 2720-2725.

Assil IQ, Abou-Samra AB (2001) N-glycosylation of CRF receptor type 1 is important for its ligand-specific interaction. Am J Physiol Endocrinol Metab 281: E1015-1021.

Baeuerle PA, Baltimore D (1988) I $\varkappa$ B: a specific inhibitor of the NF$x \mathrm{~B}$ transcription factor. Science 242: 540-546.

Bale TL, Vale WW (2004) CRF and CRF receptors: role in stress responsivity and other behaviors. Annu Rev Pharmacol Toxicol 44: 525557.

Bauman J, Jearawiriyapaisarn N, Kole R (2009) Therapeutic potential of splice-switching oligonucleotides. Oligonucleotides 19: 1-14.

Bjarnadottir TK, Geirardsdottir K, Ingemansson M, Mirza MA, Fredriksson R, Schioth HB (2007) Identification of novel splice variants of adhesion $G$ protein-coupled receptors. Gene 387: 38-48.
Blomeyer D, Treutlein J, Esser G, Schmidt MH, Schumann G, Laucht M (2008) Interaction between CRHR1 gene and stressful life events predicts adolescent heavy alcohol use. Biol Psychiatry 63: 146-151.

Bohm M, Luger TA, Tobin DJ, Garcia-Borron JC (2006) Melanocortin receptor ligands: new horizons for skin biology and clinical dermatology. I Invest Dermatol 126: 1966-1975.

Carlson KW, Nawy SS, Wei ET, Sadee W, Filov VA, Rezsova VV, Slominski A, Quillan JM (2001) Inhibition of mouse melanoma cell proliferation by corticotropin-releasing hormone and its analogs. Anticancer Res 21: 1173-1179.

Chang CP, Pearse RV 2nd, O’Connell S, Rosenfeld MG (1993) Identification of a seven transmembrane helix receptor for corticotropin-releasing factor and sauvagine in mammalian brain. Neuron 11: 1187-1195.

Charmandari E, Tsigos C, Chrousos G (2005) Endocrinology of the stress response. Annu Rev Physiol 67: 259-284.

Chen R, Lewis KA, Perrin MH, Vale WW (1993) Expression cloning of a human corticotropin-releasing-factor receptor. Proc Natl Acad Sci USA 90: 8967-8971.

Chen AM, Perrin MH, Digruccio MR, Vaughan JM, Brar BK, Arias CM, Lewis KA, Rivier JE, Sawchenko PE, Vale WW (2005) A soluble mouse brain splice variant of type 2alpha corticotropin-releasing factor (CRF) receptor binds ligands and modulates their activity. Proc Natl Acad Sci USA 102: 2620-2625.

Chrousos GP (1995) The hypothalamic-pituitary-adrenal axis and immune-mediated inflammation. N Engl J Med 332: 1351-1363.

Chrousos GP, Gold PW (1992) The concepts of stress and stress system disorders. Overview of physical and behavioral homeostasis. IAMA 267: 1244-1252.

Clarke TK, Treutlein J, Zimmermann US, Kiefer F, Skowronek MH, Rietschel M, Mann K, Schumann G (2008) HPA-axis activity in alcoholism: examples for a gene-environment interaction. Addict Biol 13: $1-14$.

Clifton VL, Telfer JF, Thompson AJ, Cameron IT, Teoh TG, Lye SJ, Challis JR (1998) Corticotropin-releasing hormone and proopiomelanocortin-derived peptides are present in human myometrium. J Clin Endocrinol Metab 83: 3716-3721.

Conn PM, Ulloa-Aguirre A, Ito J, Janovick JA (2007) G proteincoupled receptor trafficking in health and disease: lessons learned to prepare for therapeutic mutant rescue in vivo. Pharmacol Rev 59: $225-250$.

Dautzenberg FM, Kilpatrick GJ, Hauger RL, Moreau J (2001) Molecular biology of the CRH receptors - in the mood. Peptides 22: 753-760.

Deak T, Nguyen KT, Ehrlich AL, Watkins LR, Spencer RL, Maier SF, Licinio J, Wong ML, Chrousos GP, Webster E, Gold PW (1999) The impact of the nonpeptide corticotropin-releasing hormone antagonist antalarmin on behavioral and endocrine responses to stress. Endocrinology 140: 79-86.

Duvernay MT, Filipeanu CM, Wu G (2005) The regulatory mechanisms of export trafficking of $G$ protein-coupled receptors. Cell Signal 17: 1457-1465.

Eckart K, Jahn O, Radulovic J, Radulovic M, Blank T, Stiedl O, Brauns O, Tezval H, Zeyda T, Spiess J (2002) Pharmacology and biology of corticotropin-releasing factor (CRF) receptors. Receptors Channels 8: 163-177.

Eckert RL, Crish JF, Efimova T, Dashti SR, Deucher A, Bone F, Adhikary G, Huang G, Gopalakrishnan R, Balasubramanian S (2004) Regulation of involucrin gene expression. I Invest Dermatol 123: $13-22$

Einstein R, Jordan H, Zhou W, Brenner M, Moses EG, Liggett SB (2008) Alternative splicing of the $G$ protein-coupled receptor superfamily in human airway smooth muscle diversifies the complement of receptors. Proc Natl Acad Sci USA 105: 5230-5235.

Eves PC, MacNeil S, Haycock JW (2006) $\alpha$-Melanocyte stimulating hormone, inflammation and human melanoma. Peptides 27: 444-452.

Fazal N, Slominski A, Choudhry MA, Wei ET, Sayeed MM (1998) Effect of CRF and related peptides on calcium signaling in human and rodent melanoma cells. FEBS Lett 435: 187-190.

Ganceviciene R, Graziene V, Fimmel S, Zouboulis CC (2009) Involvement of the corticotropin-releasing hormone system in the pathogenesis of acne vulgaris. Br J Dermatol 160: 345-352.

Gao L, He P, Sha J, Liu C, Dai L, Hui N, Ni X (2007) Corticotropinreleasing hormone receptor type 1 and type 2 mediate differential effects on 15-hydroxy prostaglandin dehydrogenase expression in cultured human chorion trophoblasts. Endocrinology 148: 3645-3654.

Gkountelias K, Tselios T, Venihaki M, Deraos G, Lazaridis I, Rassouli O, Gravanis A, Liapakis G (2009) Alanine scanning mutagenesis of the second extracellular loop of type 1 corticotropin-releasing factor receptor revealed residues critical for peptide binding. Mol Pharmacol 75: 793-800.

Grammatopoulos DK, Chrousos GP (2002) Functional characteristics of CRH receptors and potential clinical applications of CRH-receptor antagonists. Trends Endocrinol Metab 13: 436-444. 
Grammatopoulos D, Thompson S, Hillhouse EW (1995) The human myometrium expresses multiple isoforms of the corticotropin-releasing hormone receptor. J Clin Endocrinol Metab 80: 2388-2393.

Grammatopoulos DK, Dai Y, Randeva HS, Levine MA, Karteris E, Easton AJ, Hillhouse EW (1999) A novel spliced variant of the type 1 corticotropin-releasing hormone receptor with a deletion in the seventh transmembrane domain present in the human pregnant term myometrium and fetal membranes. Mol Endocrinol 13: 21892202.

Grammatopoulos DK, Randeva HS, Levine MA, Katsanou ES, Hillhouse EW (2000) Urocortin, but not corticotropin-releasing hormone $(\mathrm{CRH})$, activates the mitogen-activated protein kinase signal transduction pathway in human pregnant myometrium: an effect mediated via R1alpha and R2beta CRH receptor subtypes and stimulation of Gq-proteins. Mol Endocrinol 14: 2076-2091.

Gulyas J, Rivier C, Perrin M, Koerber SC, Sutton S, Corrigan A, Lahrichi SL, Craig AG, Vale W, Rivier J (1995) Potent, structurally constrained agonists and competitive antagonists of corticotropinreleasing factor. Proc Natl Acad Sci USA 92: 10575-10579.

Gurevich VV, Gurevich EV (2008) GPCR monomers and oligomers: it takes all kinds. Trends Neurosci 31: 74-81.

Hauger RL, Risbrough V, Brauns O, Dautzenberg FM (2006) Corticotropin releasing factor $(\mathrm{CRF})$ receptor signaling in the central nervous system: new molecular targets. CNS Neurol Disord Drug Targets 5: $453-479$.

Hemley CF, McCluskey A, Keller PA (2007) Corticotropin releasing hormone - a GPCR drug target. Curr Drug Targets 8: 105-115.

Hillhouse EW, Grammatopoulos DK (2006) The molecular mechanisms underlying the regulation of the biological activity of corticotropin-releasing hormone receptors: implications for physiology and pathophysiology. Endocr Rev 27: 260-286.

Hillhouse EW, Randeva H, Ladds G, Grammatopoulos D (2002) Corticotropin-releasing hormone receptors. Biochem Soc Trans 30: 428-432.

Hofmann BA, Sydow S, Jahn O, van Werven L, Liepold T, Eckart K, Spiess J (2001) Functional and protein chemical characterization of the N-terminal domain of the rat corticotropin-releasing factor receptor 1. Protein Sci 10: 2050-2062.

Holmes KD, Babwah AV, Dale LB, Poulter MO, Ferguson SS (2006) Differential regulation of corticotropin releasing factor $1 \alpha$ receptor endocytosis and trafficking by $\beta$-arrestins and Rab GTPases. $J$ Neurochem 96: 934-949.

Hunt G, Todd C, Kyne S, Thody AJ (1994) ACTH stimulates melanogenesis in cultured human melanocytes. J Endocrinol 140: R1-3.

Ito N, Ito T, Betterman A, Paus R (2004) The human hair bulb is a source and target of CRH. I Invest Dermatol 122: 235-237.

Itoi K, Helmreich DL, Lopez-Figueroa MO, Watson SJ (1999) Differential regulation of corticotropin-releasing hormone and vasopressin gene transcription in the hypothalamus by norepinephrine. $J$ Neurosci 19: $5464-5472$.

Jin D, He P, You X, Zhu X, Dai L, He Q, Liu C, Hui N, Sha J, Ni $\mathrm{X}$ (2007) Expression of corticotropin-releasing hormone receptor type 1 and type 2 in human pregnant myometrium. Reprod Sci 14: $568-577$.

Jones TS, Kaste SC, Liu W, Cheng C, Yang W, Tantisira KG, Pui CH, Relling MV (2008) CRHR1 polymorphisms predict bone density in survivors of acute lymphoblastic leukemia. J Clin Oncol 26: 30313037 .

Karalis K, Sano H, Redwine J, Listwak S, Wilder RL, Chrousos GP (1991) Autocrine or paracrine inflammatory actions of corticotropin-releasing hormone in vivo. Science 254: 421-423.

Karteris E, Grammatopoulos D, Dai Y, Olah KB, Ghobara TB, Easton A, Hillhouse EW (1998) The human placenta and fetal membranes express the corticotropin-releasing hormone receptor 1 alpha $(\mathrm{CRH}-1 \alpha)$ and the CRH-C variant receptor. J Clin Endocrinol Metab 83: $1376-1379$.

Kauser S, Schallreuter KU, Thody AJ, Gummer C, Tobin DJ (2003) Regulation of human epidermal melanocyte biology by beta-endorphin. I Invest Dermatol 120: 1073-1080.

Kauser S, Slominski A, Wei ET, Tobin DJ (2006) Modulation of the human hair follicle pigmentary unit by corticotropin-releasing hormone and urocortin peptides. FASEB J 20: 882-895.

Kole R, Williams T, Cohen L (2004) RNA modulation, repair and remodeling by splice switching oligonucleotides. Acta Biochim Pol 51: 373-378.

Kraetke O, Wiesner B, Eichhorst J, Furkert J, Bienert M, Beyermann M (2005) Dimerization of corticotropin-releasing factor receptor type 1 is not coupled to ligand binding. J Recept Signal Transduct Res 25: $251-276$.

Laflamme N, Feuvrier E, Richard D, Rivest S (1999) Involvement of serotonergic pathways in mediating the neuronal activity and genetic transcription of neuroendocrine corticotropin-releasing factor in the brain of systemically endotoxin-challenged rats. Neuroscience $\mathbf{8 8}$ $223-240$.
Lagerstrom MC, Schioth HB (2008) Structural diversity of G proteincoupled receptors and significance for drug discovery. Nat Rev Drug Discov 7: 339-357.

Lewis BP, Green RE, Brenner SE (2003) Evidence for the widespread coupling of alternative splicing and nonsense-mediated mRNA decay in humans. Proc Natl Acad Sci USA 100: 189-192.

Lezoualc'h F, Engert S, Berning B, Behl C (2000) Corticotropin-releasing hormone-mediated neuroprotection against oxidative stress is associated with the increased release of non-amyloidogenic amyloid $\beta$ precursor protein and with the suppression of nuclear factor $x \mathrm{~B}$. Mol Endocrinol 14: 147-159.

Lima JJ, Blake KV, Tantisira KG, Weiss ST (2009) Pharmacogenetics of asthma. Curr Opin Pulm Med 15: 57-62.

Liu Z, Zhu F, Wang G, Xiao Z, Wang H, Tang J, Wang X, Qiu D, Liu W, Cao Z, Li W (2006) Association of corticotropin-releasing hormone receptor 1 gene SNP and haplotype with major depression. Neurosci Lett 404: 358-362.

Luger T, Paus R, Lipton J, Slominski A (1999) Cutaneous neuromodulation: the proopiomelanocortin system. Ann N Y Acad Sci USA 885: $1-479$.

Markovic D, Papadopoulou N, Teli T, Randeva H, Levine MA, Hillhouse EW, Grammatopoulos DK (2006) Differential responses of corticotropin-releasing hormone receptor type 1 variants to protein kinase C phosphorylation. J Pharmacol Exp Ther 319: 1032-1042.

Markovic D, Vatish M, Gu M, Slater D, Newton R, Lehnert H, Grammatopoulos DK (2007) The onset of labor alters corticotropinreleasing hormone type 1 receptor variant expression in human myometrium: putative role of interleukin-1ß. Endocrinology 148: 3205-3213.

Markovic D, Lehnert H, Levine MA, Grammatopoulos DK (2008) Structural determinants critical for localization and signaling within the seventh transmembrane domain of the type 1 corticotropin releasing hormone receptor: lessons from the receptor variant R1d. Mol Endocrinol 22: 2505-2519.

Mikhailova MV, Mayeux PR, Jurkevich A, Kuenzel WJ, Madison F, Periasamy A, Chen Y, Cornett LE (2007) Heterooligomerization between vasotocin and corticotropin-releasing hormone $(\mathrm{CRH})$ receptors augments CRH-stimulated 3',5'-cyclic adenosine monophosphate production. Mol Endocrinol 21: 2178-2188.

Miller LJ, Dong M, Harikumar KG, Gao F (2007) Structural basis of natural ligand binding and activation of the Class II G-protein-coupled secretin receptor. Biochem Soc Trans 35: 709-712.

Minneman KP (2001) Splice variants of G protein-coupled receptors. Mol Interv 1: 108-116.

Muller MB, Preil J, Renner U, Zimmermann S, Kresse AE, Stalla GK, Keck ME, Holsboer F, Wurst W (2001) Expression of CRHR1 and CRHR2 in mouse pituitary and adrenal gland: implications for HPA system regulation. Endocrinology 142: 4150-4153.

Myers DA, Trinh JV, Myers TR (1998) Structure and function of the ovine type 1 corticotropin releasing factor receptor (CRF1) and a carboxyl-terminal variant. Mol Cell Endocrinol 144: 21-35.

Nag K, Sultana N, Kato A, Hirose S (2007) Headless splice variant acting as dominant negative calcitonin receptor. Biochem Biophys Res Commun 362: 1037-1043.

Nelson CP, Challiss RA (2007) "Phenotypic" pharmacology: the influence of cellular environment on $G$ protein-coupled receptor antagonist and inverse agonist pharmacology. Biochem Pharmacol 73: $737-751$.

Ohmori N, Itoi K, Tozawa F, Sakai Y, Sakai K, Horiba N, Demura H, Suda T (1995) Effect of acetylcholine on corticotropin-releasing factor gene expression in the hypothalamic paraventricular nucleus of conscious rats. Endocrinology 136: 4858-4863.

Owens MJ, Nemeroff CB (1991) Physiology and pharmacology of corticotropin-releasing factor. Pharmacol Rev 43: 425-473.

Paez Pereda M, Sauer J, Perez Castro C, Finkielman S, Stalla GK, Holsboer F, Arzt E (1995) Corticotropin-releasing hormone differentially modulates the interleukin-1 system according to the level of monocyte activation by endotoxin. Endocrinology 136: 5504-5510.

Parham KL, Zervou S, Karteris E, Catalano RD, Old RW, Hillhouse EW (2004) Promoter analysis of human corticotropin-releasing factor (CRF) type 1 receptor and regulation by CRF and urocortin. Endocrinology 145: 3971-3983.

Paschos KA, Kolios G, Chatzaki E (2009) The corticotropin-releasing factor system in inflammatory bowel disease: Prospects for new therapeutic approaches. Drug Discov Today 14: 713-720.

Pawelek JM, Chakraborty AK, Osber MP, Orlow SJ, Min KK, Rosenzweig KE, Bolognia JL (1992) Molecular cascades in UV-induced melanogenesis: a central role for melanotropins? Pigment Cell Res 5: 348-356.

Perrin MH, DiGruccio MR, Koerber SC, Rivier JE, Kunitake KS, Bain DL, Fischer WH, Vale WW (2003) A soluble form of the first extracellular domain of mouse type $2 \beta$ corticotropin-releasing factor receptor reveals differential ligand specificity. J Biol Chem 278: 15595-15600.

Perrin MH, Fischer WH, Kunitake KS, Craig AG, Koerber SC, Cervini LA, Rivier JE, Groppe JC, Greenwald J, Moller Nielsen S, Vale 
WW (2001) Expression, purification, and characterization of a soluble form of the first extracellular domain of the human type 1 corticotropin releasing factor receptor. J Biol Chem 276: 31528-31534.

Perrin MH, Grace CR, Riek R, Vale WW (2006) The three-dimensional structure of the N-terminal domain of corticotropin-releasing factor receptors: sushi domains and the B1 family of $G$ protein-coupled receptors. Ann N Y Acad Sci 1070: 105-119.

Perrin MH, Vale WW (1999) Corticotropin releasing factor receptors and their ligand family. Ann N Y Acad Sci USA 885: 312-328.

Pisarchik A, Slominski AT (2001) Alternative splicing of CRH-R1 receptors in human and mouse skin: identification of new variants and their differential expression. Faseb J 15: 2754-2756.

Pisarchik A, Slominski A (2002) Corticotropin releasing factor receptor type 1: molecular cloning and investigation of alternative splicing in the hamster skin. I Invest Dermatol 118: 1065-1072.

Pisarchik A, Slominski A (2004) Molecular and functional characterization of novel CRFR1 isoforms from the skin. Eur J Biochem 271: 2821-2830.

Pisarchik A, Slominski A (2006) Variants of corticotropin releasing hormone receptor type 1 and uses thereof. US Patent No 7,071,161.

Polymeropoulos MH, Torres R, Yanovski JA, Chandrasekharappa SC, Ledbetter DH (1995) The human corticotropin-releasing factor receptor (CRHR) gene maps to chromosome 17q12-q22. Genomics 28: 123-124.

Reyes TM, Lewis K, Perrin MH, Kunitake KS, Vaughan J, Arias CA, Hogenesch JB, Gulyas J, Rivier J, Vale WW, Sawchenko PE (2001) Urocortin II: a member of the corticotropin-releasing factor (CRF) neuropeptide family that is selectively bound by type 2 CRF receptors. Proc Natl Acad Sci USA 98: 2843-2848.

Rivier J, Gulyas J, Kirby D, Low W, Perrin MH, Kunitake K, DiGruccio M, Vaughan J, Reubi JC, Waser B, Koerber SC, Martinez V, Wang L, Tache Y, Vale W (2002) Potent and long-acting corticotropin releasing factor (CRF) receptor 2 selective peptide competitive antagonists. I Med Chem 45: 4737-4747.

Rivier CL, Grigoriadis DE, Rivier JE (2003) Role of corticotropin-releasing factor receptors type 1 and 2 in modulating the rat adrenocorticotropin response to stressors. Endocrinology 144: 2396-2403.

Rivier J, Gulyas J, Kunitake K, DiGruccio M, Cantle JP, Perrin MH, Donaldson C, Vaughan J, Million M, Gourcerol G, Adelson DW, Rivier C, Tache Y, Vale W (2007) Stressin1-A, a potent corticotropin releasing factor receptor 1 (CRF1) - selective peptide agonist. J Med Chem 50: 1668-1674.

Roche PJ, Crawford RJ, Fernley RT, Tregear GW, Coghlan JP (1988) Nucleotide sequence of the gene coding for ovine corticotropin-releasing factor and regulation of its mRNA levels by glucocorticoids. Gene 71: 421-431.

Ross PC, Kostas CM, Ramabhadran TV (1994) A variant of the human corticotropin-releasing factor (CRF) receptor: cloning, expression and pharmacology. Biochem Biophys Res Commun 205: 1836-1842.

Quevedo MA, Slominski A, Pinto W, Wei E, Wortsman J (2001) Pleiotropic effects of corticotropin releasing hormone (CRH) on normal human keratinocytes. In Vitro Cell Develop Biol 37A: 50-54.

Sakai K, Yamada M, Horiba N, Wakui M, Demura H, Suda T (1998) The genomic organization of the human corticotropin-releasing factor type-1 receptor. Gene 219: 125-130.

Schmid B, Blomeyer D, Treutlein J, Zimmermann US, Buchmann AF, Schmidt MH, Esser G, Rietschel M, Banaschewski T, Schumann G, Laucht M (2009) Interacting effects of CRHR1 gene and stressful life events on drinking initiation and progression among 19-yearolds. Int J Neuropsychopharmacol (CINP): 1-12.

Seck T, Baron R, Horne WC (2003) The alternatively spliced Se13 transcript of the rabbit calcitonin receptor dimerizes with the $\mathrm{C} 1 \mathrm{a}$ isoform and inhibits its surface expression. J Biol Chem 278: 2308523093.

Seck T, Pellegrini M, Florea AM, Grignoux V, Baron R, Mierke DF, Horne WC (2005) The $\delta$ e13 isoform of the calcitonin receptor forms a six-transmembrane domain receptor with dominant-negative effects on receptor surface expression and signaling. Mol Endocrinol 19: 2132-2144.

Sexton PM, Morfis M, Tilakaratne N, Hay DL, Udawela M, Christopoulos G, Christopoulos A (2006) Complexing receptor pharmacology: modulation of family B G protein-coupled receptor function by RAMPs. Ann N Y Acad Sci USA 1070: 90-104.

Shkreta L, Froehlich U, Paquet ER, Toutant J, Elela SA, Chabot B (2008) Anticancer drugs affect the alternative splicing of Bcl-x and other human apoptotic genes. Mol Cancer Ther 7: 1398-1409.

Shyu JF, Inoue D, Baron R, Horne WC (1996) The deletion of 14 amino acids in the seventh transmembrane domain of a naturally occurring calcitonin receptor isoform alters ligand binding and selectively abolishes coupling to phospholipase C. J Biol Chem 271: 31127-31134.

Sirianni R, Mayhew BA, Carr BR, Parker CR Jr, Rainey WE (2005) Corticotropin-releasing hormone $(\mathrm{CRH})$ and urocortin act through type $1 \mathrm{CRH}$ receptors to stimulate dehydroepiandrosterone sulfate production in human fetal adrenal cells. J Clin Endocrin Metab 90: 5393-5400.
Slominski AT (2006) Proopiomelanocortin signaling system is operating in mast cells. J Invest Dermat 126: 1934-1936.

Slominski A (2009a) Neuroendocrine activity of the melanocyte. Exp Dermatol 18: 760-763.

Slominski A (2009b) On the role of the corticotropin-releasing hormone signalling system in the aetiology of inflammatory skin disorders. Br J Dermatol 160: 229-232.

Slominski A, Mihm MC (1996) Potential mechanism of skin response to stress. Int J Dermatol 35: 849-851.

Slominski A, Wortsman J (2000) Neuroendocrinology of the skin. Endocrine Rev 21: 457-487.

Slominski A, Paus R, Wortsman J (1993) On the potential role of proopiomelanocortin in skin physiology and pathology. Mol Cell Endocrinol 93: C1-C6.

Slominski A, Ermak G, Hwang J, Chakraborty A, Mazurkiewicz JE, Mihm M (1995) Proopiomelanocortin, corticotropin releasing hormone and corticotropin releasing hormone receptor genes are expressed in human skin. FEBS Lett 374: 113-116.

Slominski A, Baker J, Ermak G, Chakraborty A, Pawelek J (1996a) Ultraviolet $\mathrm{B}$ stimulates production of corticotropin releasing factor (CRF) by human melanocytes. FEBS Lett 399: 175-176.

Slominski A, Ermak G, Mihm M (1996b) ACTH receptor, CYP11A1, CYP17 and CYP21A2 genes are expressed in skin. J Clin Endocrinol Metab 81: 2746-2749.

Slominski A, Ermak G, Mazurkiewicz JE, Baker J, Wortsman J (1998a) Characterization of corticotropin-releasing hormone (CRH) in human skin. J Clin Endocrinol Metab 83: 1020-1024.

Slominski A, Paus R, Mihm MC (1998b) Inhibition of melanogenesis as an adjuvant strategy in the treatment of melanotic melanomas: selective review and hypothesis. Anticancer Res 18: 3709-3715.

Slominski AT, Botchkarev V, Choudhry M, Fazal N, Fechner K, Furkert J, Krause E, Roloff B, Sayeed M, Wei E, Zbytek B, Zipper J, Wortsman J, Paus R (1999) Cutaneous expression of CRH and CRH-R. Is there a "skin stress response system?" Ann N Y Acad Sci USA 885: 287-311.

Slominski A, Szczesniewski A, Wortsman J (2000a) Liquid chromatography-mass spectrometry detection of corticotropin-releasing hormone and proopiomelanocortin-derived peptides in human skin. $J$ Clin Endocrinol Metab 85: 3582-3588.

Slominski A, Wortsman J, Luger T, Paus R, Solomon S (2000b) Corticotropin releasing hormone and proopiomelanocortin involvement in the cutaneous response to stress. Physiol Rev 80: 979-1020.

Slominski AT, Roloff B, Zbytek B, Wei ET, Fechner K, Curry J, Wortsman J (2000c) Corticotropin releasing hormone and related peptides can act as bioregulatory factors in human keratinocytes. In Vitro Cell Dev Biol Anim 36: 211-216.

Slominski A, Wortsman J, Pisarchik A, Zbytek B, Linton EA, Mazurkiewicz JE, Wei ET (2001) Cutaneous expression of corticotropinreleasing hormone $(\mathrm{CRH})$, urocortin, and $\mathrm{CRH}$ receptors. Faseb J 15: $1678-1693$.

Slominski A, Wortsman J, Linton E, Pisarchik A, Zbytek B (2003) The skin as a model for the immunodulatory effects of corticotropinreleasing hormone. In Mind over Matter - Regulation of Peripheral Inflammation by the CNS. Schäfer M, Stein C, eds, 1 edn, pp 149-176. Birkhäuser Verlag, Basel.

Slominski A, Pisarchik A, Tobin DJ, Mazurkiewicz JE, Wortsman J (2004a) Differential expression of a cutaneous corticotropin-releasing hormone system. Endocrinology 145: 941-950.

Slominski A, Tobin DJ, Shibahara S, Wortsman J (2004b) Melanin pigmentation in mammalian skin and its hormonal regulation. Physiol Rev 84: 1155-1228.

Slominski A, Zbytek B, Pisarchik A, Slominski RM, Zmijewski MA, Wortsman J (2006a) CRH functions as a growth factor/cytokine in the skin. J Cell Physiol 206: 780-791.

Slominski A, Zbytek B, Zmijewski M, Slominski RM, Kauser S, Wortsman J, Tobin DJ (2006b) Corticotropin releasing hormone and the skin. Front Biosci 11: 2230-2248.

Slominski A, Wortsman J, Tuckey RC, Paus R (2007a) Differential expression of HPA axis homolog in the skin. Mol Cell Endocrinol 265-266: 143-149.

Slominski AT, Zmijewski MA, Pisarchik A, Wortsman J (2007b) Molecular cloning and initial characterization of African green monkey (Cercopithecus aethiops) corticotropin releasing factor receptor type 1 (CRF1) from COS-7 cells. Gene 389: 154-162.

Slominski A, Wortsman J, Paus R, Elias PM, Tobin DJ, Feingold KR (2008) Skin as an endocrine organ: implications for its function. Drug Discov Today Dis Mech 5: 137-144.

Smith AI, Funder JW (1988) Proopiomelanocortin processing in the pituitary, central nervous system, and peripheral tissues. Endocr Rev 9: $159-179$.

Spiess J, Rivier J, Rivier C, Vale W (1981) Primary structure of corticotropin-releasing factor from ovine hypothalamus. Proc Natl Acad Sci USA 78: 6517-6521.

Sumanasekera C, Watt DS, Stamm S (2008) Substances that can change alternative splice-site selection. Biochem Soc Trans 36: 483-490. 
Sydow S, Radulovic J, Dautzenberg FM, Spiess J (1997) Structurefunction relationship of different domains of the rat corticotropinreleasing factor receptor. Brain Res 52: 182-193.

Sztainberg Y, Kuperman Y, Issler O, Gil S, Vaughan J, Rivier J, Vale W, Chen A (2009) A novel corticotropin-releasing factor receptor splice variant exhibits dominant negative activity: a putative link to stress-induced heart disease. FASEB J 23: 2186-2196.

Tache Y, Bonaz B (2007) Corticotropin-releasing factor receptors and stress-related alterations of gut motor function. J Clin Invest 117: 33-40.

Teli T, Markovic D, Hewitt ME, Levine MA, Hillhouse EW, Grammatopoulos DK (2008) Structural domains determining signalling characteristics of the CRH-receptor type 1 variant R1beta and response to PKC phosphorylation. Cell Signal 20: 40-49.

Theoharides TC, Donelan JM, Papadopoulou N, Cao J, Kempuraj D, Conti P (2004) Mast cells as targets of corticotropin-releasing factor and related peptides. Trends Pharmacol Sci 25: 563-568.

Tsai-Morris CH, Buczko E, Geng Y, Gamboa-Pinto A, Dufau ML (1996) The genomic structure of the rat corticotropin releasing factor receptor. A member of the class II G protein-coupled receptors. J Biol Chem 271: 14519-14525.

Turnbull AV, Rivier CL (1999) Regulation of the hypothalamic-pituitary-adrenal axis by cytokines: actions and mechanisms of action. Physiol Rev 79: 1-71.

Vale W, Spiess J, Rivier C, Rivier J (1981) Characterization of a 41-residue ovine hypothalamic peptide that stimulates secretion of corticotropin and $\beta$-endorphin. Science 213: 1394-1397.

Vale WW, Bale TL, Lee K-F, Smith GW (2004) Corticotropin releasing factor receptor 2 deficient mice and uses thereof. US Patent 20040034882.

Van Pett K, Viau V, Bittencourt JC, Chan RK, Li HY, Arias C, Prins GS, Perrin M, Vale W, Sawchenko PE (2000) Distribution of mRNAs encoding CRF receptors in brain and pituitary of rat and mouse. J Comp Neurol 428: 191-212.

Wasserman D, Sokolowski M, Rozanov V, Wasserman J (2008) The CRHR1 gene: a marker for suicidality in depressed males exposed to low stress. Genes Brain Behav 7: 14-19.

Webster EL, Lewis DB, Torpy DJ, Zachman EK, Rice KC, Chrousos GP (1996) In vivo and in vitro characterization of antalarmin, a nonpeptide corticotropin-releasing hormone $(\mathrm{CRH})$ receptor antagonist: suppression of pituitary ACTH release and peripheral inflammation. Endocrinology 137: 5747-5750.

Wei ET, Thomas HA (1994) Correlation of neuroendocrine and antiedema activities of alanine-corticotropin-releasing factor analogs. Eur J Pharmacol 263: 319-321.

Wei E, Slominski A (2002) Inhibition of abnormal cell growth with corticotropin-releasing hormone analogs. Patent US 2002142962; WO0153777.

Wiesner B, Roloff B, Fechner K, Slominski A (2003) Intracellular calcium measurements of single human skin cells after stimulation with corticotropin-releasing factor and urocortin using confocal laser scanning microscopy. J Cell Sci 116: 1261-1268.

Xiong Y, Xie LY, Abou-Samra AB (1995) Signaling properties of mouse and human corticotropin-releasing factor (CRF) receptors: decreased coupling efficiency of human type II CRF receptor. Endocrinology 136: 1828-1834.

Young SF, Griffante C, Aguilera G (2007) Dimerization between vasopressin $\mathrm{V} 1 \mathrm{~b}$ and corticotropin releasing hormone type 1 receptors. Cell Mol Neurobiol 27: 439-461.

Zbytek B, Slominski AT (2005) Corticotropin-releasing hormone induces keratinocyte differentiation in the adult human epidermis. $J$ Cell Physiol 203: 118-126.

Zbytek B, Slominski AT (2007) CRH mediates inflammation induced by lipopolysaccharide in human adult epidermal keratinocytes. J Invest Dermatol 127: 730-732.

Zbytek B, Pfeffer LM, Slominski AT (2003) Corticotropin-releasing hormone inhibits nuclear factor $x \mathrm{~B}$ pathway in human $\mathrm{HaCaT}$ keratinocytes. I Invest Dermatol 121: 1496-1499.

Zbytek B, Pfeffer LM, Slominski AT (2004) Corticotropin-releasing hormone stimulates $\mathrm{NF} x \mathrm{~B}$ in human epidermal keratinocytes. $J$ Endocrinol 181: R1-7.

Zbytek B, Pikula M, Slominski RM, Mysliwski A, Wei E, Wortsman J, Slominski AT (2005) Corticotropin-releasing hormone triggers differentiation in HaCaT keratinocytes. Br J Dermatol 152: 474-480.

Zbytek B, Pfeffer LM, Slominski AT (2006a) CRH inhibits NFxB signaling in human melanocytes. Peptides 27: 3276-3283.

Zbytek B, Wortsman J, Slominski A (2006b) Characterization of a ultraviolet B-induced corticotropin-releasing hormone-proopiomelanocortin system in human melanocytes. Mol Endocrinol 20: 2539-2547.

Zhao J, Karalis KP (2002) Regulation of nuclear factor $x \mathrm{~B}$ by corticotropin-releasing hormone in mouse thymocytes. Mol Endocrinol 16: 2561-2570.

Zmijewski MA, Slominski AT (2009a) CRF1 receptor splicing in epidermal keratinocytes: potential biological role and environmental regulations. J Cell Physiol 218: 593-602.

Zmijewski MA, Slominski AT (2009b) Modulation of CRF singaling throught receptor splicing in mouse AtT-20 pituitary cells Emerging role of soluble isoforms. J Physiol Pharmacol 60: 39-46.

Zmijewski MA, Sharma RK, Slominski AT (2007) Expression of molecular equivalent of hypothalamic-pituitary-adrenal axis in adult retinal pigment epithelium. J Endocrinol 193: 157-169.

Zouboulis CC, Seltmann H, Hiroi N, Chen W, Young M, Oeff M, Scherbaum WA, Orfanos CE, McCann SM, Bornstein SR (2002) Corticotropin-releasing hormone: an autocrine hormone that promotes lipogenesis in human sebocytes. Proc Natl Acad Sci USA 99: 7148-7153.

Zoumakis E, Rice KC, Gold PW, Chrousos GP (2006) Potential uses of corticotropin-releasing hormone antagonists. Ann N Y Acad Sci USA 1083: 239-251. 